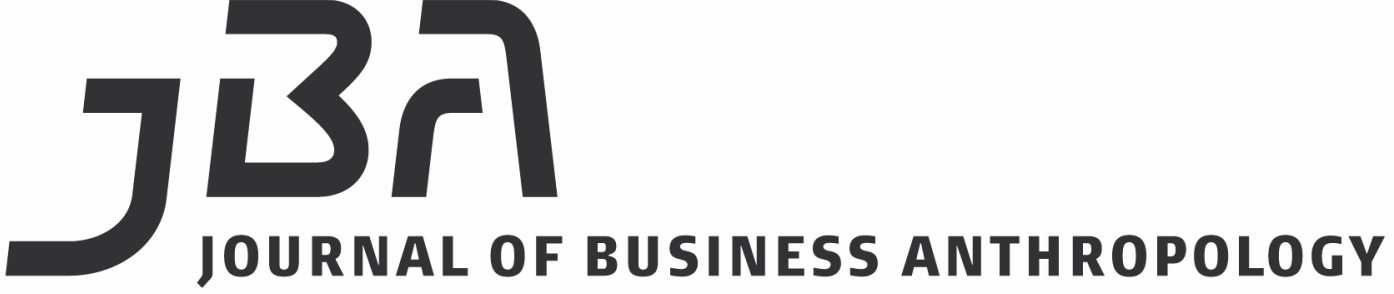

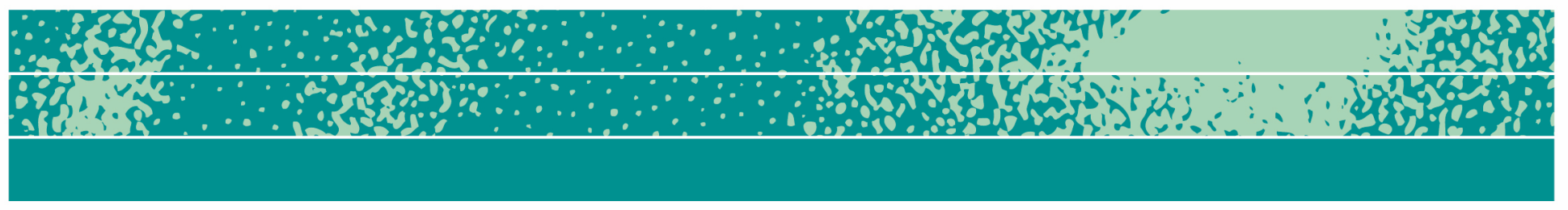

\section{Transportation and Change through an Anthropological Lens}

\author{
Mari H. Clarke
}

\begin{abstract}
This paper provides a broad overview of anthropological research on roads and transport as a prelude and context for the other papers in this themed issue. The paper begins with a short historical overview of anthropological approaches to roads and transportation. Then it offers a case study on how roads both facilitated and reflected major socioeconomic changes in Methana, Greece, reflecting change in the broader context of Greece society. Next, it describes applied social analysis approaches to the design of roads that emerged from the World Bank and related organizations. Finally, it explores the current flowering of anthropological research on roads, which encompasses technopolitical, political ecology, spatial, and semiotic analyses. A second case study describes efforts to build a "culture" of inclusive road stewardship through a World Bank financed rural roads project in Vietnam. The paper concludes by reflecting on possible future directions for transport anthropology, which offers strategic opportunities to influence large infrastructure investments, transport policy, and anthropological theory.
\end{abstract}

\section{Key words}

Transport, Roads, Infrastructure, Vietnam, Greece, Gender, Practice 


\section{Introduction}

In the past, roads and other means of transportation remained in the shadows of anthropological inquiry - largely ways to reach study sites. More recently, many anthropologists are focusing on roads, drawing on a range of theoretical perspectives such as political ecology, technopolitics, social justice, and semiotics. This research is situated in an increased interest in infrastructure (Dalakoglou 2017a). Anthropologists are also conducting research on the experiences of road users, such as bicyclists, motorcyclists, taxi drivers, truckers, and pedestrians, in increasingly urbanized, congested, and complex road networks. An "anthropology of roads" has been proposed by a number of scholars. This paper provides a broad overview of anthropological research on roads and transport, including mine, as a prelude and context for the other papers in this themed issue, which focus more closely on the experience of particular road user groups or designers of transportation systems.

The paper begins with a short historical overview of anthropological approaches to roads and transportation. Then it offers a case study based on ethnographic research in the 1970s and 1980s. Next, it describes applied social analysis approaches to the design of roads that emerged from the World Bank and related organizations. Finally, it explores the current flowering of anthropological research on roads, and again provides an illustrative case study. The paper concludes by reflecting on possible future directions and strategic opportunities for transport anthropology.

Whether it is characterized as "transport anthropology," "anthropology of roads," or other terms, despite a wide range of theoretical directions, the core of anthropological work focused on transport is the interface of humans, in all their diversity, with material, political, and other dimensions of transportation systems large or small.

\section{Historical Overview}

Many early ethnographers, including Franz Boaz and Claude Lévi Strauss, described the challenges faced in traveling to research sites as they sought the most isolated and "exotic" cultures. To many, roads threatened to change the isolated cultures they sought to capture in ethnographies (Dalakoglou 2017a, 22-23). Lévi-Strauss, for instance, wrote that "the establishment of the new federal capital of Brazil and the building of roads and aerodromes in remote parts of South America have led to the discovery of small tribes in areas where no native life was thought to exist" $(1971,45)$.

By the middle of the twentieth century, anthropologists began to acknowledge that the arrival of roads signaled the end of isolated cultures, and incorporated roads in their studies. Even earlier, Max 
Gluckman's analysis of dynamics of Zulu and European social relations at the opening ceremony for a road bridge (1940) led the way for future generations of anthropological studies of the power of colonial infrastructure constructed for resource extraction (Dalakoglou 2017a).

By the 1960s, anthropologists began viewing roads as important aspects of research, and debated how much emphasis to place on material and cultural dimensions (Dalakoglou 2017, 23-24). Many looked at perceptions of social and economic impacts of ideas, technologies, and goods coming in and people migrating out on roads. For example, David Hayano's Road Through the Rainforest in Papua New Guinea detailed the ethnographer's personal fieldwork experience engaging with local people who anxiously awaited the construction of a road that was a metaphor for development for some and a source of fear of change and out-migration of the young for others (1990). Pamela Stewart and Andrew Strathern's tale of a harrowing, bandit-ridden drive from Highland Papua New Guinea to the port of Lae is interwoven with recollections of research by anthropologists in areas passed, and comments on changes brought by the road (1999).

Both Joao Pina Cabral and Sharon Roseman analyzed local perceptions of roads, in Portugal and Galicia Spain respectively. Cabral's "peasants" opposed paved roads while Rosen's farmers viewed them as critical turning points and indicators of social and economic progress. Both locations had a long history of labor migration (Cabral 1987; Roseman 1996). From a different theoretical perspective, Anthony Wallace described driving to work in the U.S. in terms of individual cognitive processes required to obey rules of the road, manage driving, and follow routes (1971).

\section{Case Study: Roads from Subsistence to Consumerism on Methana, Greece}

I conducted research on the changing smallholder household economy on the volcanic peninsula of Methana, in the Saronic Gulf of Greece, for two years in the mid-1970s and two years in the mid-1980s. My regional analysis framework, built on Emmanuel Wallerstein's notion of the world system and core-periphery relationships (Smith 1976), combined with a systems-oriented cultural ecological perspective (Netting et. al 1984; Netting 1993), led me to look beyond my research site to changing transport, social, and economic linkages between villages, the port town, the region, Athens, and the nation. In addition, local people insisted that the road was the most significant factor affecting their quality of life. The opening of the road was their reference point for important events, described as "before" or "after" the road.

Despite their simple two-room houses and mule-driven farming technology deployed on narrow stone terraces on the mountainside, 
Methanites were by no means isolated from the larger economy, even before the road. Their household strategy of "a little bit of everything" applied to crops, labor migration, work in the merchant marine, investment in land on the plain of Trizinia and Piraeus, and entrepreneurship, selling noodles, wild oregano, almonds and figs, and renting rooms to tourists taking healing baths in the port town.

Before the road was built, only steep stony mule paths led between villages, the port town, and docking places for small boats (Bory de Sint Vincent 1834), as well as the plain of Trizinia where some owned land (see Figure 1) (Great Britain Naval Intelligence Division 1945). Boats - first sail then motorized - were the main modes of travel to Piraeus and the islands of Aegina and Poros. Depending on the village, travel to the port town by mule or foot took one to three hours.

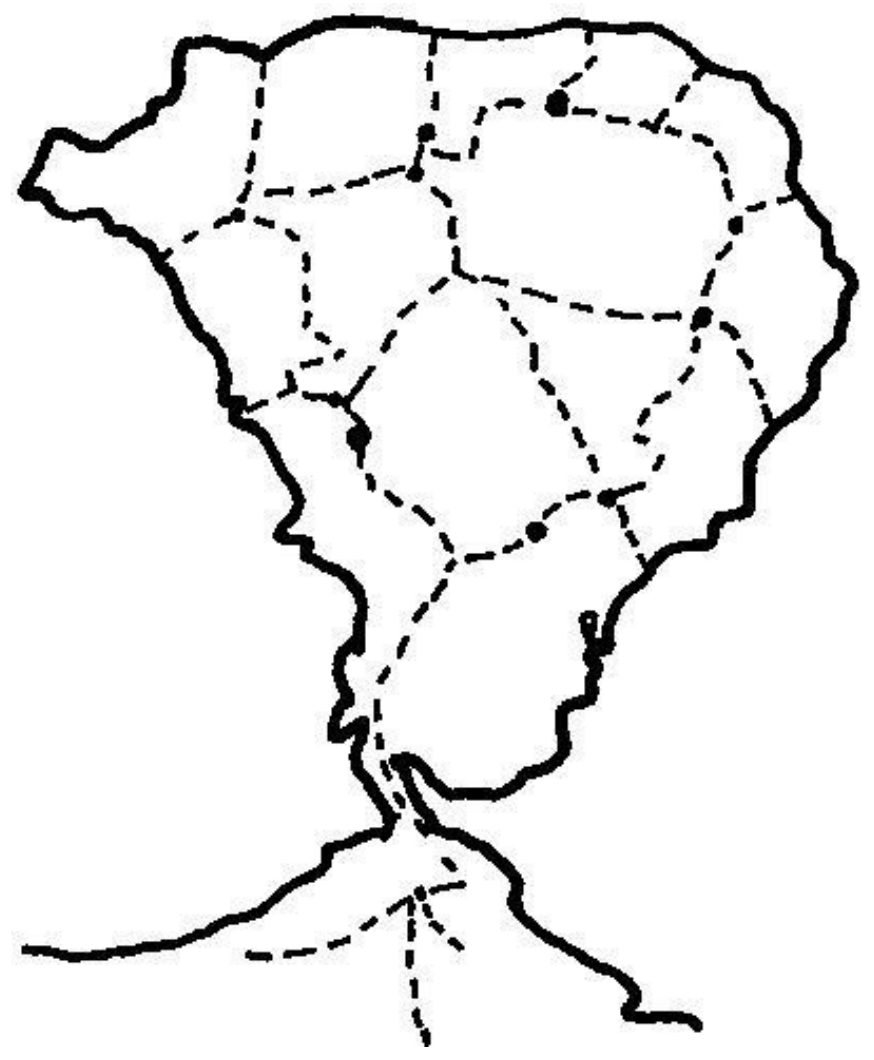

Figure 1. Methana Paths, 1834

During World War II, a paved vehicle road was constructed as far as the port town of Loutra (see Figure 2) (Great Britain Naval Intelligence Division 1945). 


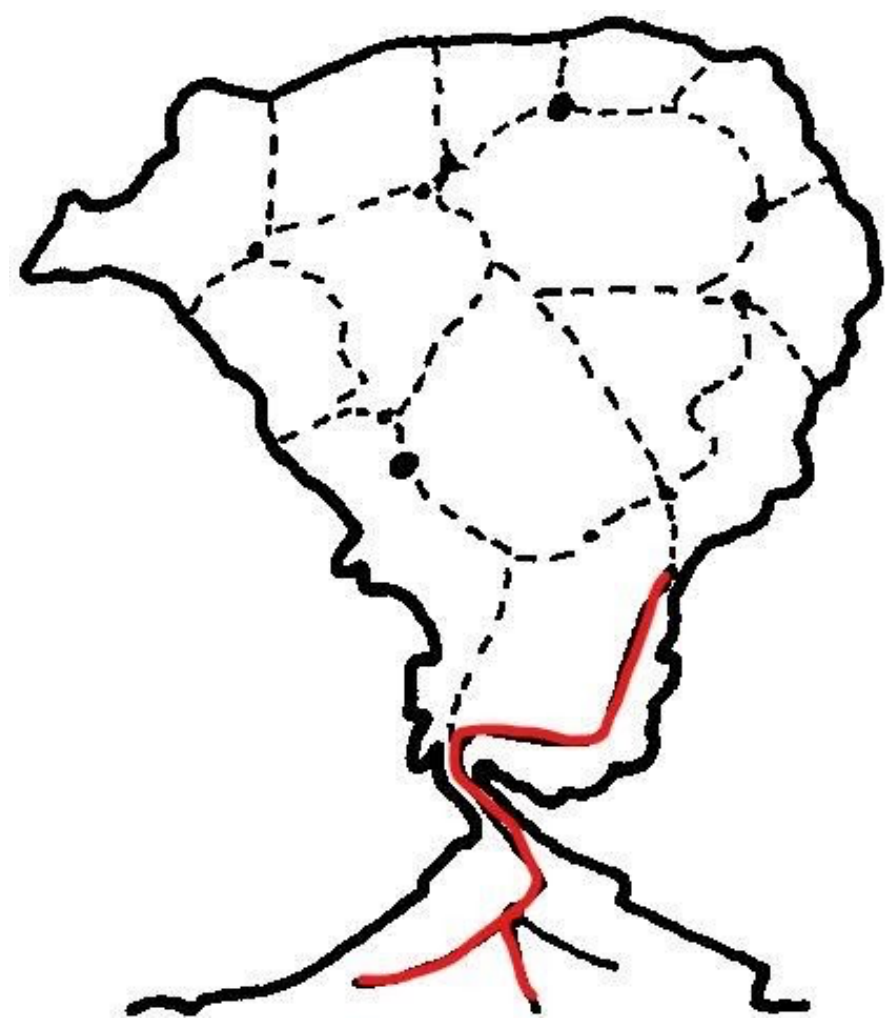

Figure 2. Methana Roads, 1944

By 1960, the road reached the two nearest villages (Figure 3), assisted by voluntary labor from local men.

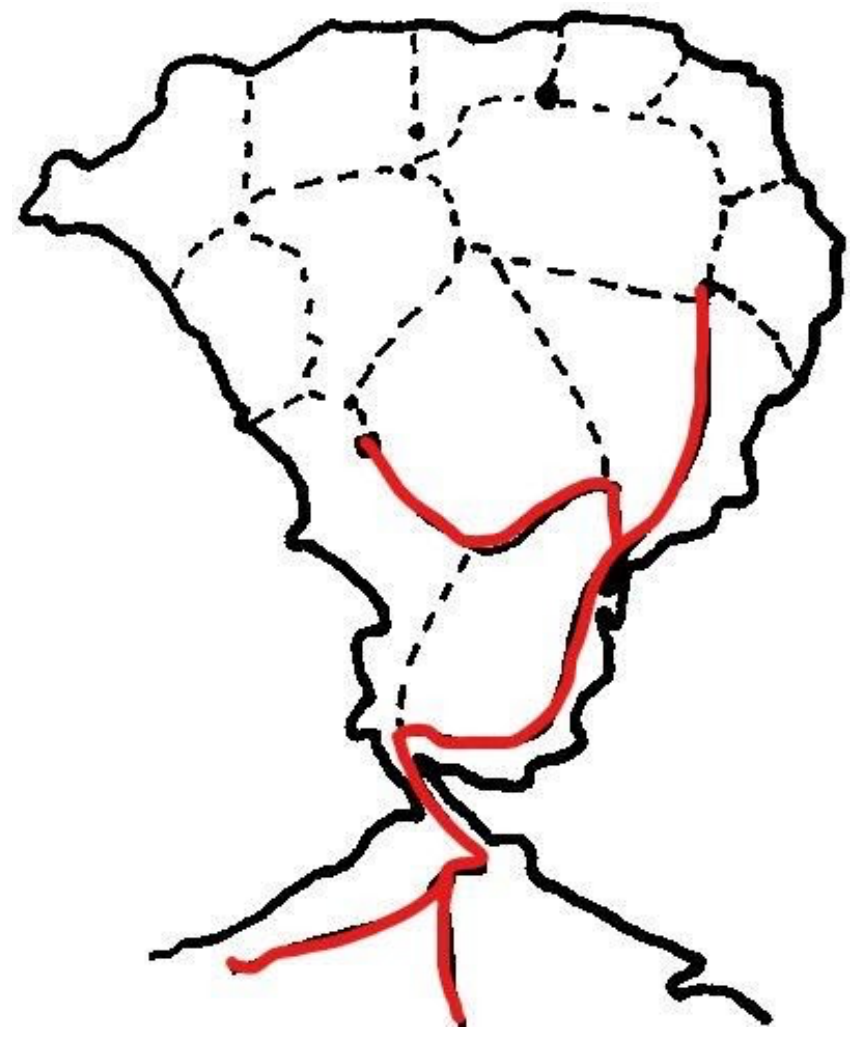

Figure 3. Methana Roads, 1960 
Photo 1 shows villagers providing labor on the road.

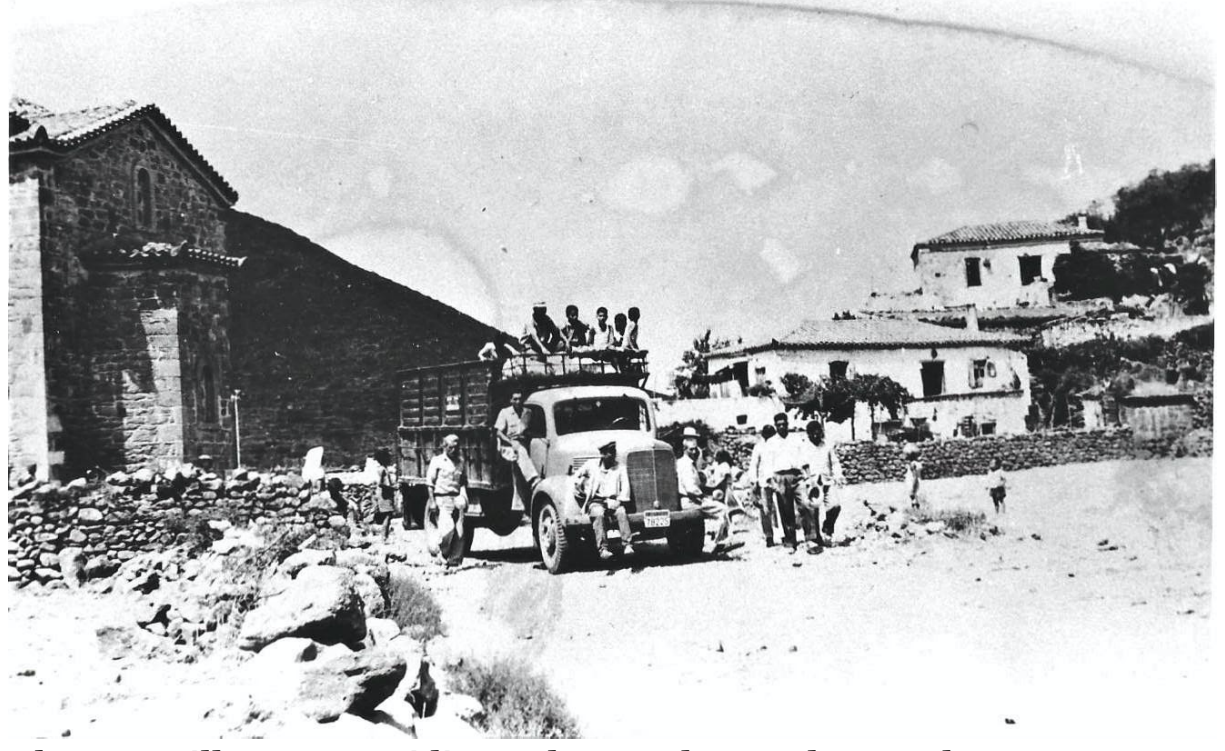

Photo 1. Villagers Providing Labor on the Road around 1960

By 1975 (Figure 4), the road extended to all of the villages on the peninsula. Using the road, the port was fifteen to thirty minutes away by car, bus, or taxi. Roads also offered an alternate route to Athens when seas were too rough for the ferry. Most Methanites still travelled to Piraeus by ferryboat or hydrofoil in good weather because it was faster.

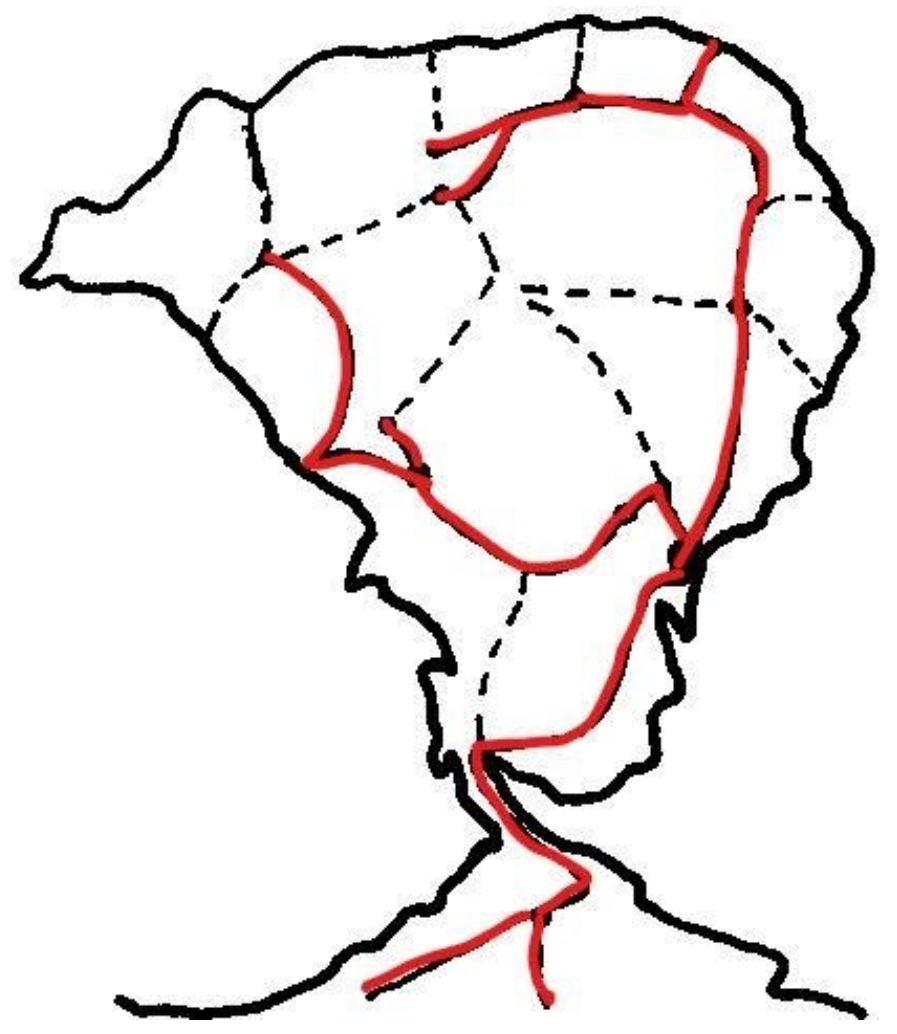

Figure 4. Methana Roads, 1975 
With the road came electricity, running water, schoolteachers, a local bus service, and a threshing machine service that replaced mules circling on stone threshing floors, as shown in Photo 2.

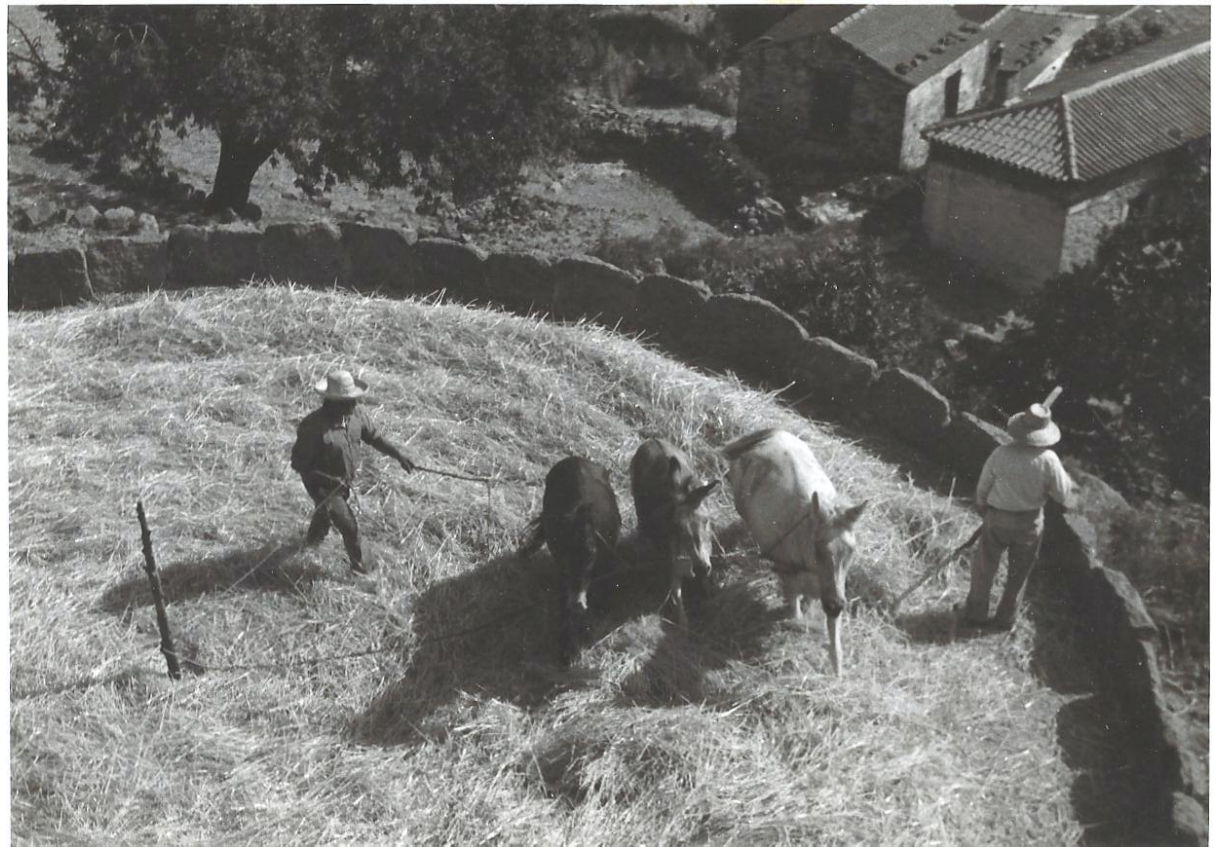

\section{Photo 2. Threshing Grain on a Stone Threshing Floor around 1975}

The expansion of the national road system increased the importance of trucks for transporting goods. This facilitated trade between Methana, Argos, and Nauplion. One of the men in my research site purchased a truck soon after the road opened to earn income transporting goods, while his wife and daughter tended the crops. Photo 3 shows the wife plowing their field. Another man sold fruit in a shop in the port town. Still another ran a small hotel there (Clark 1988, 1994, 2000).

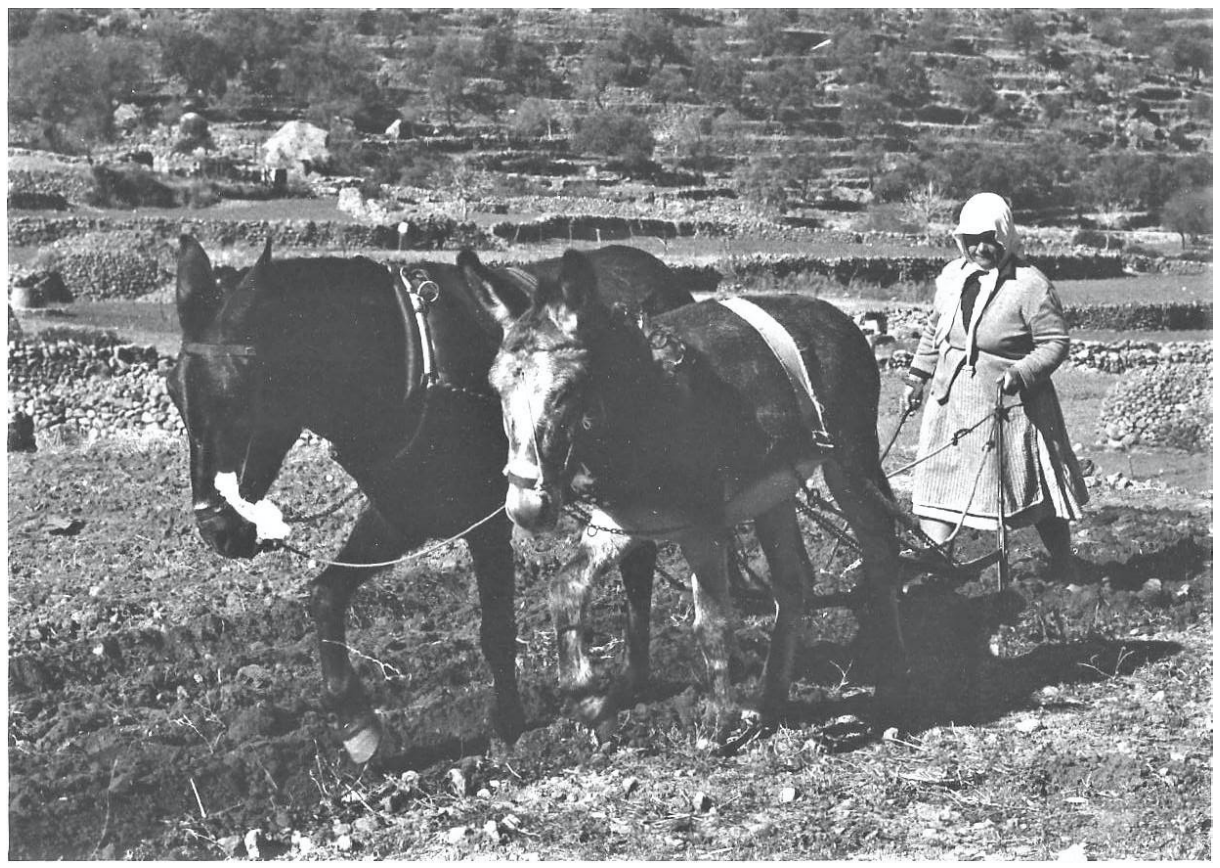

Photo 3. Wife of a Trucker Plowing the Field with Mules around 1975 
By the mid-1980s, roads reached fields high on the mountain and down to the sea (Figure 5), enabling villagers to harvest their olives, wheat, grapes, and figs more easily with trucks and to use rototillers instead of mule driven plows on narrow stone-terraced fields. The road also made house construction and renovation much easier. ${ }^{1}$ By the mid1980's, most households had indoor plumbing, flush toilets, refrigerators, stoves, televisions, and other conveniences.

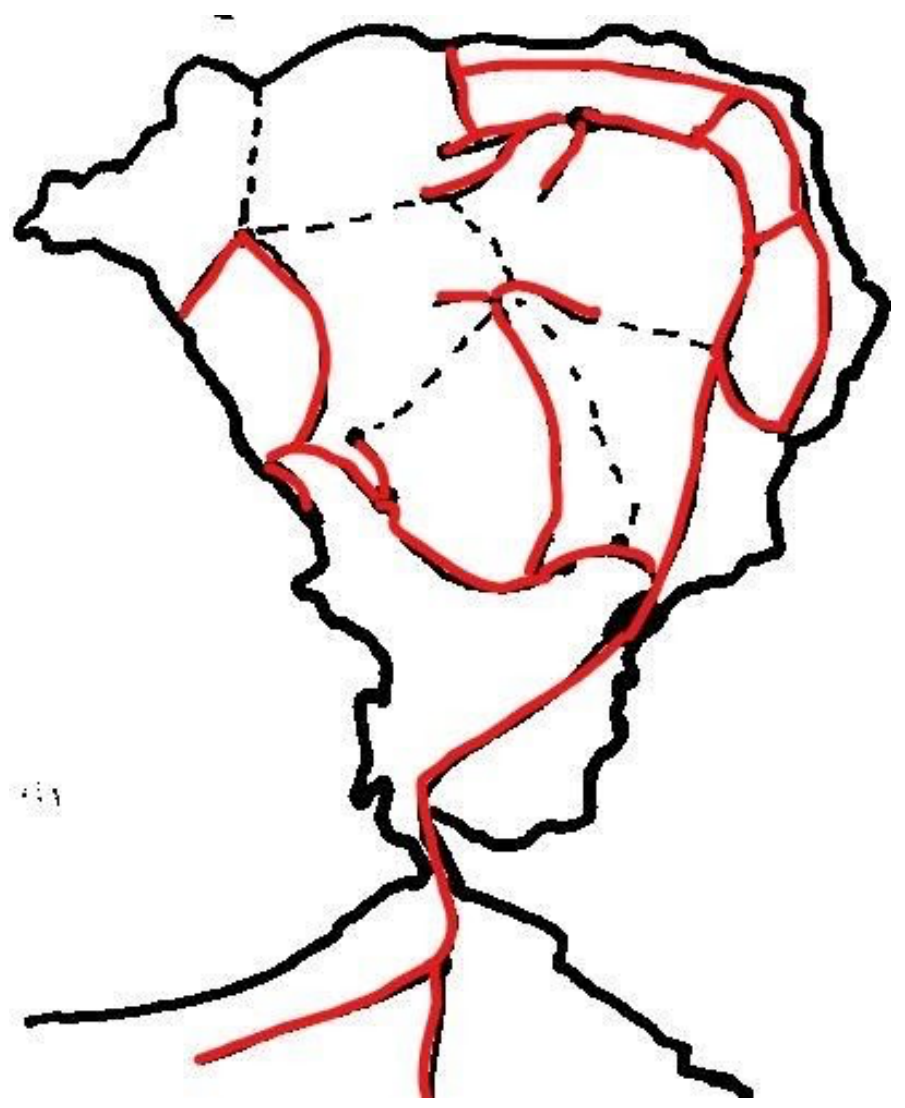

Figure 5. Methana Roads, 1984

As children migrated to the port city or Athens for employment in skilled trades and business, village household size shrank, but houses expanded, emulating homes in suburban Athens. People spent less time farming, cultivated less land, and used trucks to carry the harvest. They enjoyed leisure time to visit relatives, travel to monasteries, and watch television. Their urban children often visited the village on weekends and holidays, and contributed to the renovation of homes (Clark 1994, 51923). The road network has continued to expand; Figure 6 shows the roads in 2019.

\footnotetext{
${ }^{1}$ In the village where I was based, 27 households did major renovations between 1972 and 1987, adding bedrooms, kitchens, and bathrooms.
} 


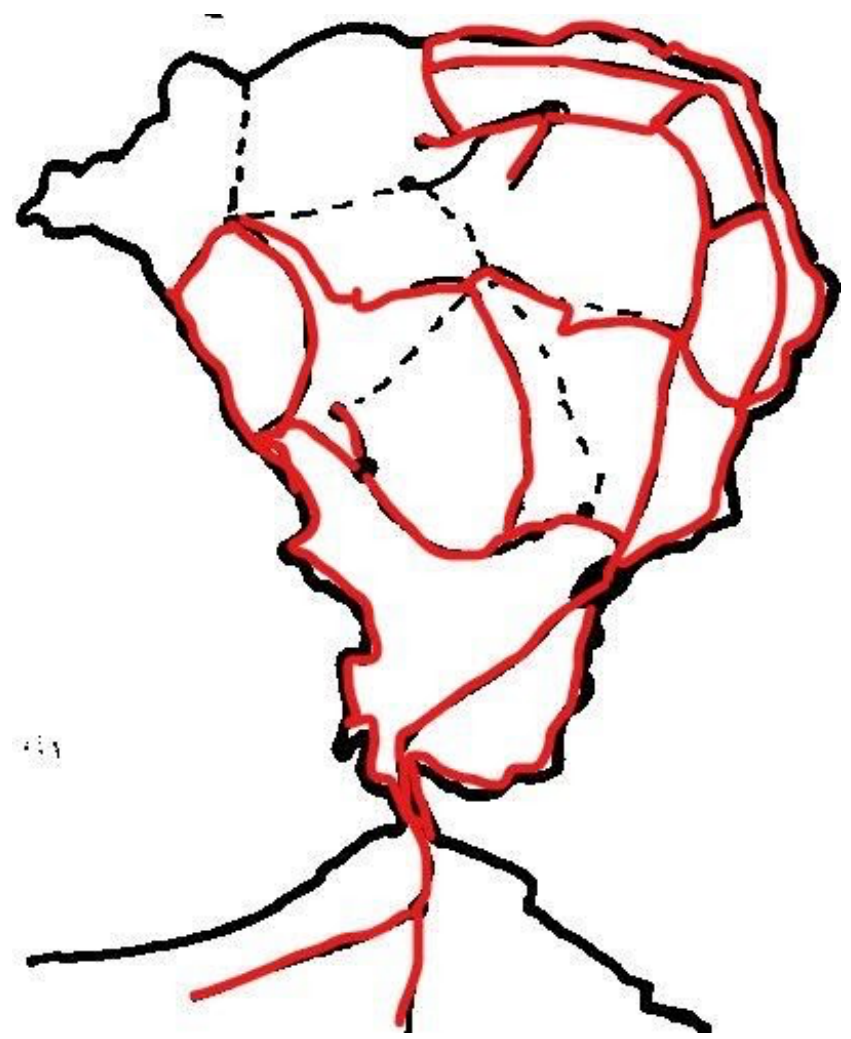

Figure 6. Methana Roads, 2019

Today Google Earth shows a tree-lined road extending along a large part of Methana's coastline (Photo 4), dotted with vacation cottages, condominiums, hotels, and restaurants as well as beaches and docks for pleasure boats. (Google Earth 2019; Schorr 2017).

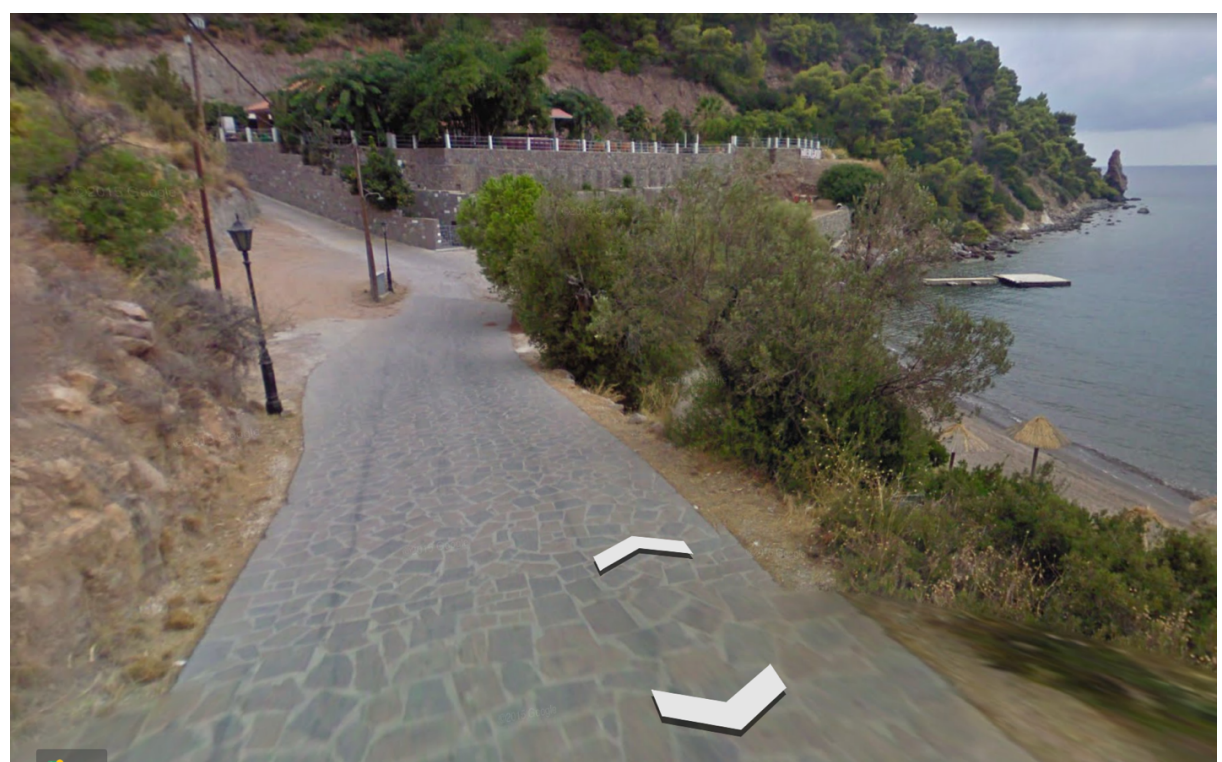

Photo 4. Coastal Road and Limnioni Beach, Eastern Side of Methana 2019 (Credit: Google Earth)

Methana has become a weekend retreat for Athenians and a tourism destination for other Greeks. Roads extend over the volcanic mountainside (Photo 5). Few of the narrow, terraced fields on the mountainside are cultivated. 


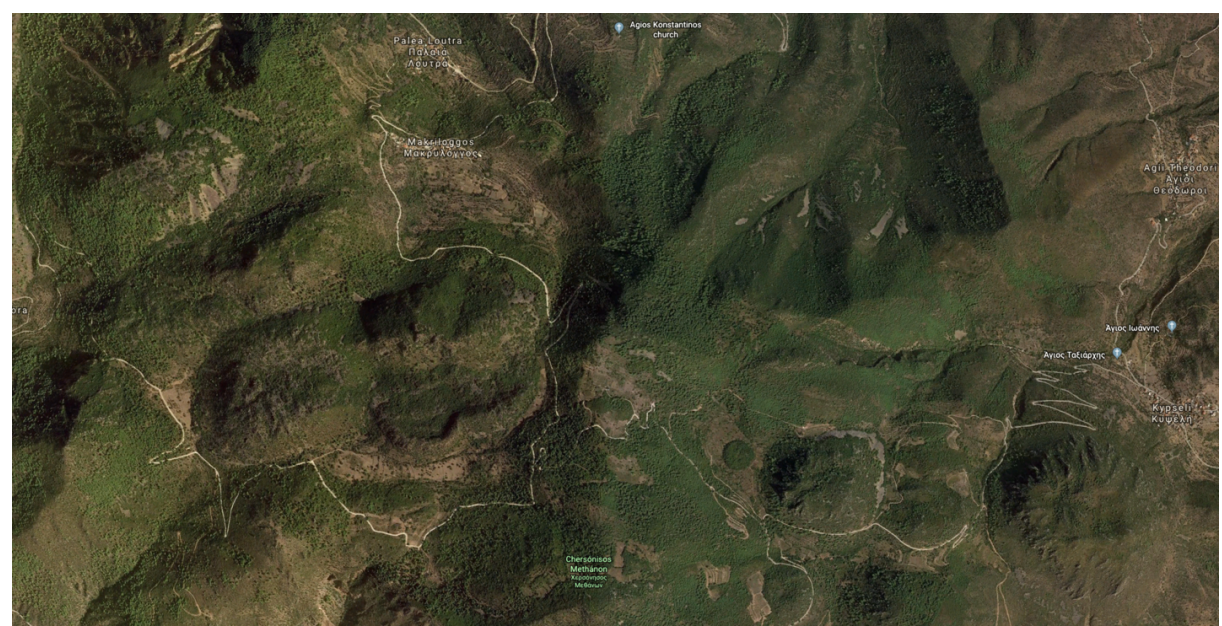

Photo 5. Roads over the Top of Methana's Volcanic Mountains 2019

(Credit: Google Earth)

Land near the sea, once valued for farming, is now for sale as lots for vacation cottages or in use for seaside retreats of Methanites living in Athens. The port town of Methana has expanded its port and beach, as shown in Photo 6.

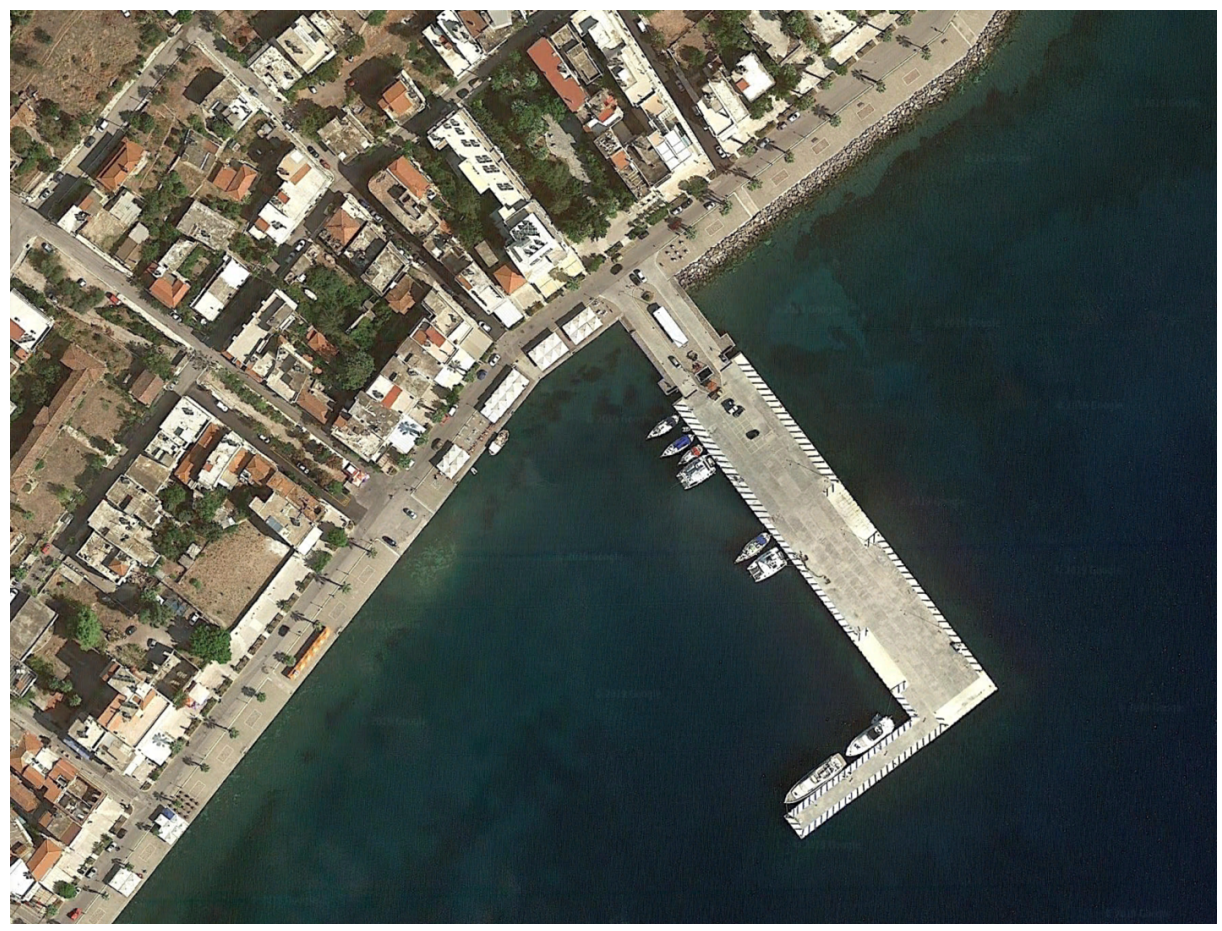

Photo 6. Port Town of Methana Including Ferry Dock 2019 (Credit: Google Earth) 
On the western coast of the peninsula, the small harbor of Vathi expanded hotels and restaurants, as shown in Photo 7. The tiny village of Kaimeni Hora opened an amphitheater in a volcanic crater with programs for tourists. Volcano tours are also offered by a German tour guide (Schorr 2017).

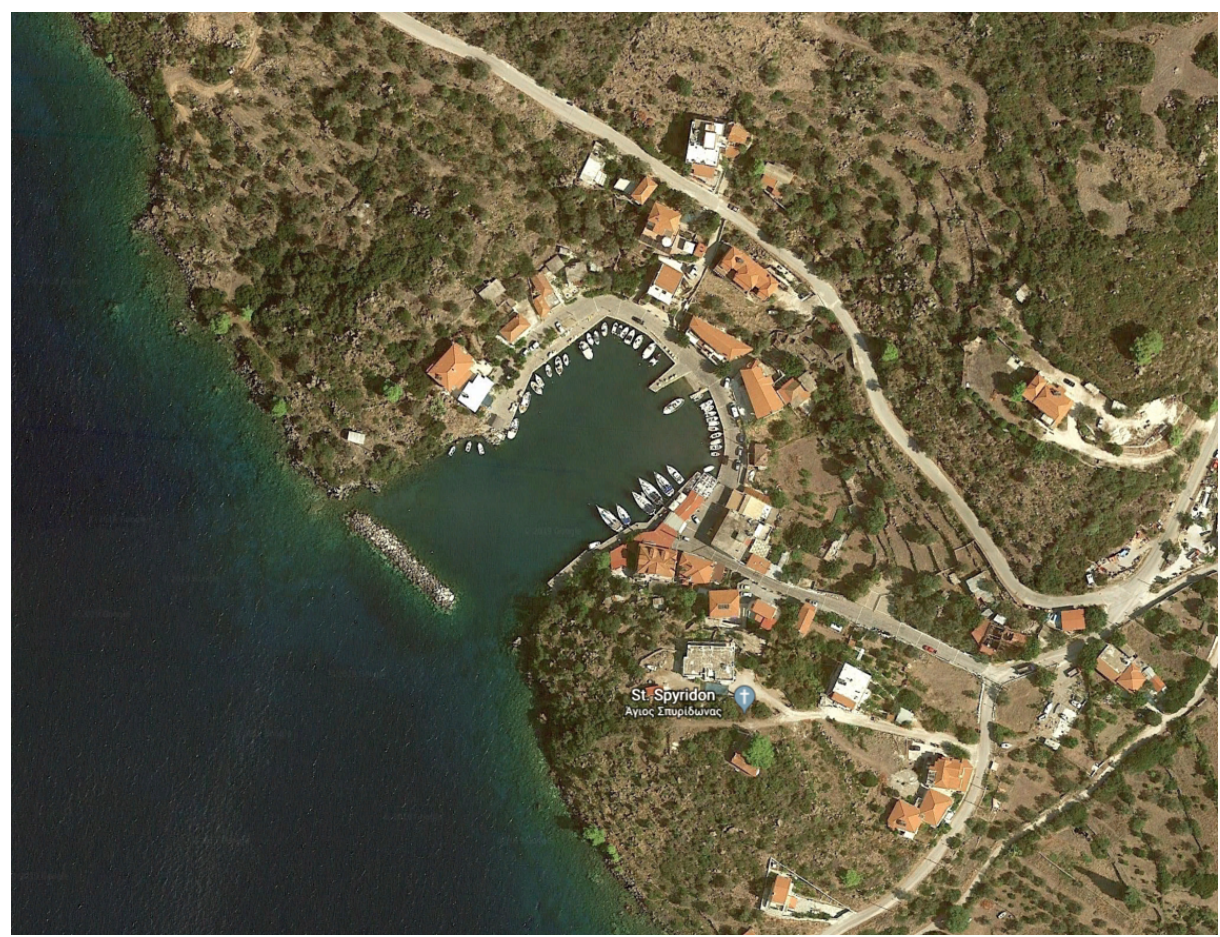

Photo 7. Vathi Harbor, Hotel and Restaurant, Western Side of Methana 2019 (Credit: Google Earth)

It is a very different landscape from the peninsula where I conducted my research, and roads are a key part of the change.

In summary, the introduction and expansion of the road system on Methana revealed by Figures 1-6 both facilitated and reflected broader socio-economic changes in Greece, particularly the growth of nearby Athens as the political, economic, and cultural center of Greece. Over time, Methanites shifted from two-room houses as shelters for themselves and livestock, to multiroom villas with modern plumbing, decorations, and flowers and fruit trees in the yard. The mode of production shifted from semi-subsistence agriculture to increasing wage labor and small businesses, with growing emphasis on tourism. Multigenerational households (stem families) were replaced by nuclear households and widows or widowers living alone. The lifestyle changed from frugality to consumerism, following a similar shift in Athens (Economou 2014, 1415). Methanites moved from the periphery to the Athens core of power through migration and through pursuit of tourism-related enterprises on Methana. The elaborate stone terrace walls and paths leading to them the infrastructure of the semi-subsistence past - are crumbling in disrepair and paved over by road networks and other infrastructure of consumerism and the tourism economy. 


\section{Putting People First in the Design of Roads}

In a separate and applied stream of anthropological research, practitioners have carried out social and impact studies of road and other infrastructure projects around the globe, aiming to put people first in development projects, and assess the negative as well as positive impacts of these projects (Cook 1991; Kudat 1996; Kudat et.al 1997; Moran 1981; Porter 2002; Trankell 1993). Michael Cernea, the World Bank's first social scientist, was an early advocate for social analysis of World Bank infrastructure projects. He stressed that "people are - and should - be the starting point, the center, and the end of each development effort" (Cernea 1985, xiv).

Since 1958, the Gwembe Tonga research project, initiated by Thayer Scudder and Elizabeth Colson, has documented the negative impacts of Kariba Hydroelectric Dam on the Gwembe Tonga, due to resettlement (Scudder 2007) and later road and irrigation projects (Harnish et. al. 2018). Emilio Moran analyzed the impact of settlements along the Trans-Amazon Highway (1981).

Cernea and other World Bank social scientists leveraged this and other impact research to persuade World Bank leaders to adopt a "safeguard" policy in 1980 to minimize resettlement, require social and ecological impact assessments, and set standards and regulate compensation and livelihood restoration for all World Bank financed projects. Similar policies have been adopted by major development agencies and governments in all 25 Organization for Economic Cooperation and Development Countries (Cernea 2008).

By the late 1990s, gender, ethnic minority and other social exclusionary gaps in access to and benefits from transport projects were emerging as important social dimensions requiring research to inform project designs and evaluations. For example, Ayse Kudat's assessment of the potential impacts of a proposed transport project in Ashgabat Turkmenistan found that privatization had increased fares and reduced transport access for the poor, especially women (Kudat 1996). ${ }^{2}$

Recognizing that women and men had different travel patterns based on their social roles, a growing network of transport and gender researchers asked questions about what inhibits mobility and road accessibility for women and men, time and travel patterns of women, the relationship between transport and gender policies, the relationship between policy and on-the ground projects, the potential of information communication technologies for making transport projects more inclusive, and how the lack of transport increases the risk of maternal mortality (Riverson et al. 2006). The International Forum for Rural

\footnotetext{
${ }^{2}$ See Clarke 2012, 67-68 for more details on Ayse Kudat's research and contributions regarding gender and transport.
} 
Transport and Development (IFRTD) compiled local level studies funded by the United Kingdom Department for International Development (DFID) in 15 countries across Asia and Africa in Balancing the Load: Women, Gender and Transport (Fernando and Porter 2002). IFRTD also initiated the Gender and Transport Community of Practice (GATNET).

Maria Teresa Guttierez, gender specialist for the World Bank financed Peru Rural Roads Project, convinced the Peruvian government that she needed to work directly with local people to understand gender stereotypes and power relations limiting women's participation in road work. She used focus group discussions, participatory workshops, and interviews to design a gender-sensitive training program for road maintenance workers. Having women on the teams improved the quality and quantity of work, in part by keeping male workers from getting drunk on the job. Women were often elected treasurers of microenterprise cooperatives because they were considered more trustworthy than men. (Guttierez 2003; Guttierez and Kuiper 2010). ${ }^{3}$

Wendy Walker and colleagues in Lesotho applied a geographic information system (GIS) as a participatory tool to enable local women and men to map their travel pathways. This revealed significant differences in men's and women's travel patterns and constraints. Men had greater mobility, travelling greater distances on the road using motorized transport or donkeys. Women walked on footpaths perpendicular to the road, and their travel times were much longer, even though the distances were shorter. Lack of cash and social constraints often prevented women from using public transport or even donkeys. These insights were incorporated in planning for improvement of the road network (Vajji and Walker 2009; Walker and Vajjhala 2005).

\section{A Plethora of Current Research on Roads}

Anthropological research on roads has increased dramatically in the past decade. ${ }^{4}$ Studies include a wide range of theoretical perspectives by researchers from all over the globe. Dimitris Dalakoglou suggests that increased focus on roads is due to the enormous cultural impacts of increasingly extensive and complex transport networks and flows of people, goods and things (2010). Bettina Stoetzer links increased excitement about infrastructure to its usefulness as an analytical lens for understanding urgent contemporary challenges such as environmental risks of extracting resources, movements of global capital, climate change,

\footnotetext{
${ }^{3}$ See Clarke 2012:70-72 for more details on the Peru Rural Roads Project

${ }^{4}$ Luke Heslop tallied 78 papers on infrastructure in the program for the 2015 American Anthropological Association Annual Meeting. In the same year, the Group for Debates in anthropological Theory chose infrastructure as the central theme (Heslop 2016).
} 
gender and class inequalities, violence, and war (2016). Several papers in this volume reflect increasing anthropological engagement with design challenges of new technologies such as autonomous vehicles. There have also been proposals for transport anthropology (Clarke 2012), an anthropology of roads (Dalakoglou 2017a; Dalakoglou and Harvey 2012), anthropology of traffic (Rosen 2003; Yazici 2013), and anthropology of infrastructure (Star 1999; Larkin 2013; di Nunzio 2018; Stoetzer 2018).

Looking at the globalization of anthropology, this burst of attention to roads appears to be part of what Mariette Baba and Carol Hill describe a "global convergence" of theoretical and applied research. The convergence includes three dimensions: "1) a shift toward contemporary, problem-oriented interdisciplinary research, (2) participatory and collaborative methodologies, and (3) stronger profiles in policy making and political influence" (Baba and Hill 2006, 196-201). Three current projects illustrate transport anthropological work that displays these dimensions: Infra-Demos, the "Roads and the Politics of Thought" project, and the Infrastructure Toolbox.

"Infra-Demos: Socio-Technological Innovation, Infrastructural Participation and Democracy" is an anthropological project, focused on Greece, studying "relationships between infrastructures and innovative socio-technological forms of participation arising within the infrastructural gap" (infra-demos 2017). This gap emerged after the 2008 economic crisis when the state and the private sector had difficulty sustaining infrastructure. The five-year project, 2017-2022, examines how citizen participation responding to this gap can contribute to "societal resilience and transformative policies" (infra-demos 2017). It is led by anthropologist Dimitris Dalakoglou, an anthropologist at Vrije Universiteit Amsterdam.

The "Roads and the Politics of Thought" project is conducting studies of road projects in Pakistan, India, Maldives, Myanmar, and Sri Lanka, highlighting how nation-building, neo-liberalism, ambition, environmental vulnerability and modernity feature in contemporary road-building to understand the global cultures of road-building practice (SOAS 2019). This five-year project, 2014-2019, is led by Edward Simpson, an anthropologist at the School of Oriental and African Studies, University of London (SOAS).

The online "Infrastructure Toolbox" provides concepts and methods "to draw infrastructure out of the background and into the foreground of ethnographic research and theorizing" (Appel et al. 2015b). In November 2014, the authors of the Infrastructure Toolbox participated in a seminar at the School for Advanced Research in Santa Fe, New Mexico. The group explored why infrastructure, bound up with state formation and reform, has become a critical site of politics today. They examined how infrastructure produces "historically and materially 
situated forms of biopolitical government and citizenship," and "changing forms of the public and the private, of states and corporations, of citizens and consumers." They considered how infrastructure helps theorize "key anthropological questions about affect, aspiration, and imagination; about modernity, development, and temporality; and about the production of states and markets, the public and the private" (Appel et al. 2015b). The authors produced a series of thirteen blog posts in 2015 that they called the Infrastructure Toolbox (Appel et al. 2015a), as well as an edited volume (Anand et al. 2018).

\section{A Sampler of Critical Issues Analyzed in Current Road Research}

Dalakoglou and Harvey's 2012 framing of the anthropological study of roads, within the wider context of studies on mobility and modernity, provides a useful overview for the following sampler of critical issues addressed in current road research. They argue that roads connect the "sweeping narratives of globalization" with "tangible materialities of particular times and places" (Dalakoglou and Harvey 2012, 459). Infrastructure supports information society in increasing the circulation of commodified goods and labor, and extractive economies of developing nations on which production and reproduction of such goods and labor depend. Roads elicit "powerful temporal imaginaries" about the promise or threat of future connectivity and "articulate political and material histories" that often provoke controversy over roads. Such controversy is rooted in the inevitable accommodation of multiple competing interests in planning and construction of modern highways. Financial, regulatory, and technical relations often "fold international, national and local regimes into a single and specific location" in highway construction (Dalakoglou and Harvey 2012, 460).

Urban Mobility and Social Justice: Several anthropologists have examined how transportation infrastructure impacts urban mobility options and constraints where there are racial and class divides. Transport-related "fragmentation of lived experience" in suburban post-Apartheid South Africa is expected to polarize society (Czegeldy 2004, 88). Lack of sidewalks constrains suburban pedestrian mobility there and in Atlanta (Gaither et al. 2015). In Tbilisi, Georgia, car owners appropriating sidewalk for parking are shamed by young activists (Sherouse 2018). Suburbanization of poverty and gentrification of urban centers affects racialized mobilities in Philadelphia (Sheller 2015). Routing for expansion of the Tampa Bay expressway targeted Black communities, provoking activism for spatial and racial justice (Rodriguez and Ward 2018).

Contestations between State Regulators and Transport Service Providers: Others looked at the conflicts and contestations between state regulators and private transport providers. Many are informal providers, filling a void left by limited public transport capacity, and are embedded in 
extensive local social networks. In Lima, informal minibuses serving 85 percent of the commuters were finally legalized by the government due to failure of public buses (Uzzell 1987). A clash of views about modernity and regulation between public administrators and transport providers threatened the livelihoods of hereditary taxi drivers in Mumbai (Bedi 2016) and three-wheel taxi drivers in Ethiopia (Mains and Kinfu 2017). Contestations between officials and transport service drivers escalated to protests on the part of motorcycle taxi drivers in Bangkok (Sopranzetti 2014) and the three-wheel taxi drivers in Ethiopia confronting fuel shortage and fare reductions (Mains and Kinfu 2017). With deregulation, white male truckers working for the oil industry in Louisiana lost control of trucking they had leveraged through strong family and community networks. This opened trucking options for Blacks, Latinos, and women (Gardner 2002). In Nairobi, Kenya, (Ference 2016) and Hawassa, Ethiopia (Mains and Kinfu 2017) informal transport service providers were characterized as criminal, immoral and unclean by officials seeking to control their mobility.

Spatial and Socio-Political Dimensions of Traffic: This was another issue of concern. Several analyses of traffic were framed in spatial and mobility terms, often accentuating racial, caste and class divides. In India, caste distinctions shaped the location of drivers on the road (Rosin 2003). In Ho Chi Minh City, Vietnam, officials initially separated vehicles by power to maintain traffic flow (bicycles to the right, motorcycles in the middle, and cars and buses on the left) which reflected evolving class differences (Truitt 2008). In Istanbul, cross-class encounters in congestion demonstrated how social inequality was produced (Yazici 2013). In Britain, drivers negotiated their spatial co-presence through spacesharing, thus constructing traffic flow collaboratively (Haddington and Rauiomaa 2016). In Guangzhou, China, the rapid urbanization during the Late Reform Period created traffic congestion which continued to cause conflicts. The state regarded infrastructure projects as technological solutions to a wide range of social and political urban problems, but "the material results simply made these problems invisible" (Zhang 2016, 414).

Technopolitics and Political Ecology of Highways: Numerous studies examined ways in which highways were embedded in the dynamics of the state. State roadbuilding in rural Zaire aiming to foster market integration had differential impacts on life chances of different groups based on power relations regarding the control of land, labor, and goods markets, exacerbated by the economic crisis and structural adjustment policies (Fairhead 1992). In Albania, the transborder highway to Greece reflected a post-socialist transition to a market economy, massive migration to Greece, and the peripheral relation of the nation to the Western European core (Dalakoglou 2017b). Post-civil war rapid reconstruction of roads in Sri Lanka made and unmade fractured relations, pitting social and 
economic motivations of outsiders against concerns of insiders (Menzes 2017).

Andean and Amazonian roads in Peru served as territorial connectors that standardized space into socially and administratively defined domains to build a cohesive, integrated nation (Harvey and Knox 2016). In Pakistan, the M2 Highway, intended to reflect modernity with its electronic billboards and emergency phones, was too modern for existing infrastructure. Inadequate human and technological resources led to communication breakdowns and driver fears of robbery, smuggling and reluctance to travel over unfamiliar, unpopulated areas on the M2 (Kahn 2006).

In colonial Haiti, very few roads were built in order to keep workers on plantations. Late $19^{\text {th }}$ century post-colonial road construction, amplified by early $20^{\text {th }}$ century American occupation, enabled the first development of significant urban centers (Yarrington 2015). Environmental politics of unpaved roads in the Amazon (Campbell 2012) and disputes over mapping of territory to facilitate administration of indigenous people (Uribe 2019) were also examined.

Some looked as roads as barriers used for state control. The Israeli Closure policy employed roadblocks, check points and other barriers to prevent and disorient Palestinian movement in the occupied territories and into Israel (Bishara 2015). In the Central African Republic, roadblock keepers invoked the power of the state to assert their own authority and demand money and goods from travelers (Lombard 2013). In the sparse grasslands and deserts of the Sino-Mongolian border, new and upgraded roads served as "distancing technologies" discouraging interactions between local Mongolians and Chinese employed in mining and oil companies (Pederson and Bunkenborg 2012, 555).

Conflict and Violence: This was another research issue. In Peru, Shining Path rebels forced local people to cut trenches into the Frontier Road, challenging state power and asserting territorial claims by making the road impassible for troops pursuing them. Later the state constructed walls on the road to prevent narcotraffickers from using the rebuilt road as a landing strip, ignoring the accident risk they posed for local drivers (Kernaghan 2016). Roadblocks in the Central African Republic were "nodes on a map of 'anticipated violence'" in an area with minimal government control amidst rebel activity (Lombard 2013, 159). In Postwar Sri Lanka women, girls, and transgender people faced violence on public transport (Butt and Sekarami 2019).

Semiotics of Roads: Some examined the meanings embedded in roads or roadlessness. In Nigeria, the association of deadly spirits with paved roads "condenses past history" of forced labor and bloodshed on roads constructed by foreign interests for resource extraction. It also "concretizes the perils and possibilities of modern life" of emerging 
capitalism and high road accident rates (Masquelier 2002, 829). In Papua New Guinea, local Christians believed that the New Testament, translated by evangelical missionaries, was a channel to God and they expected him to answer their prayers for a paved road. When no road appeared, they felt disconnected from this channel and complained instead about walking because they had no road (Handman 2017).

In Siberia, there was a blurring of meaning between roads and roadlessness. Roads lacked permanence and were always in the making because strong winds and blizzards could easily cover tracks, so they had to be laid anew (Argounova-Low 2012, 2017). The shaming campaign waged against drivers who parked on sidewalks in Tblisi drew together various asymmetric power relations (European urban order and local frictions, Russia and Georgia, car driving elites and pro-green youth activists), without catalyzing a particular form of politics against them (Sherouse 2018).

\section{Case Study: Gender and Ethnic Inclusion on Rural Roads in Vietnam}

Since 2010, I have worked on gender and ethnic inclusion for rural road projects in Vietnam. Missing road links have isolated many rural communities from Vietnam's remarkable economic successes, particularly in the mountainous areas where most poor, ethnic minorities reside. Costs of road maintenance are high due to steep terrain, erosion, and landslides caused by increasingly extreme rainfall exacerbated by climate change. With few options for earning income, particularly for women, poor ethnic minority residents lack resources to pay for road maintenance. Commune People's Committees arranged "voluntary labor days" for community participation in road maintenance, but this only made local roads marginally open to traffic because of untrained volunteers. Viewing roads as state property, local farmers damaged roads by digging trenches across them to irrigate fields and dumping trash in roadside drainage ditches designed to carry water away from the road.

Responding to these problems, the World Bank financed rural road projects targeting poor areas. The Third Rural Transport Project (RTP3) (2006-2014) aimed to reduce travel costs and improve access to markets, off-farm economic opportunities, and social services for poor rural communities in 33 provinces through road rehabilitation and maintenance (World Bank 2006). In 2010, the project launched a small pilot program to engage ethnic minority women in routine road maintenance in one district. This expanded in 2012, working with Provincial Women's Unions in Lao Cai, Quang Binh, and Thanh Hoa Provinces. The second pilot included a campaign to raise awareness about the importance of rural road maintenance, training local people how to maintain roads, income for poor, ethnic minority women road workers, and organizational capacity building for Women's Union branches at 
provincial, district, and commune levels.

Women's Union-managed groups in three provinces maintained 3,191 kilometers (km) of road. ${ }^{5}$ Although local road maintenance was women-managed, they did not bear all the burden. Men carried out heavier tasks, such as accessing suitable materials for filling potholes, removing large stones from roadside drainage ditches and culverts, and felling trees. Women worked more hours than men, because their tasks were lighter and required more frequently (e.g. clearing rubbish and vegetation from roadside side drainage ditches and cutting grass and small bushes). Photo 8 shows road maintenance being carried out by women.

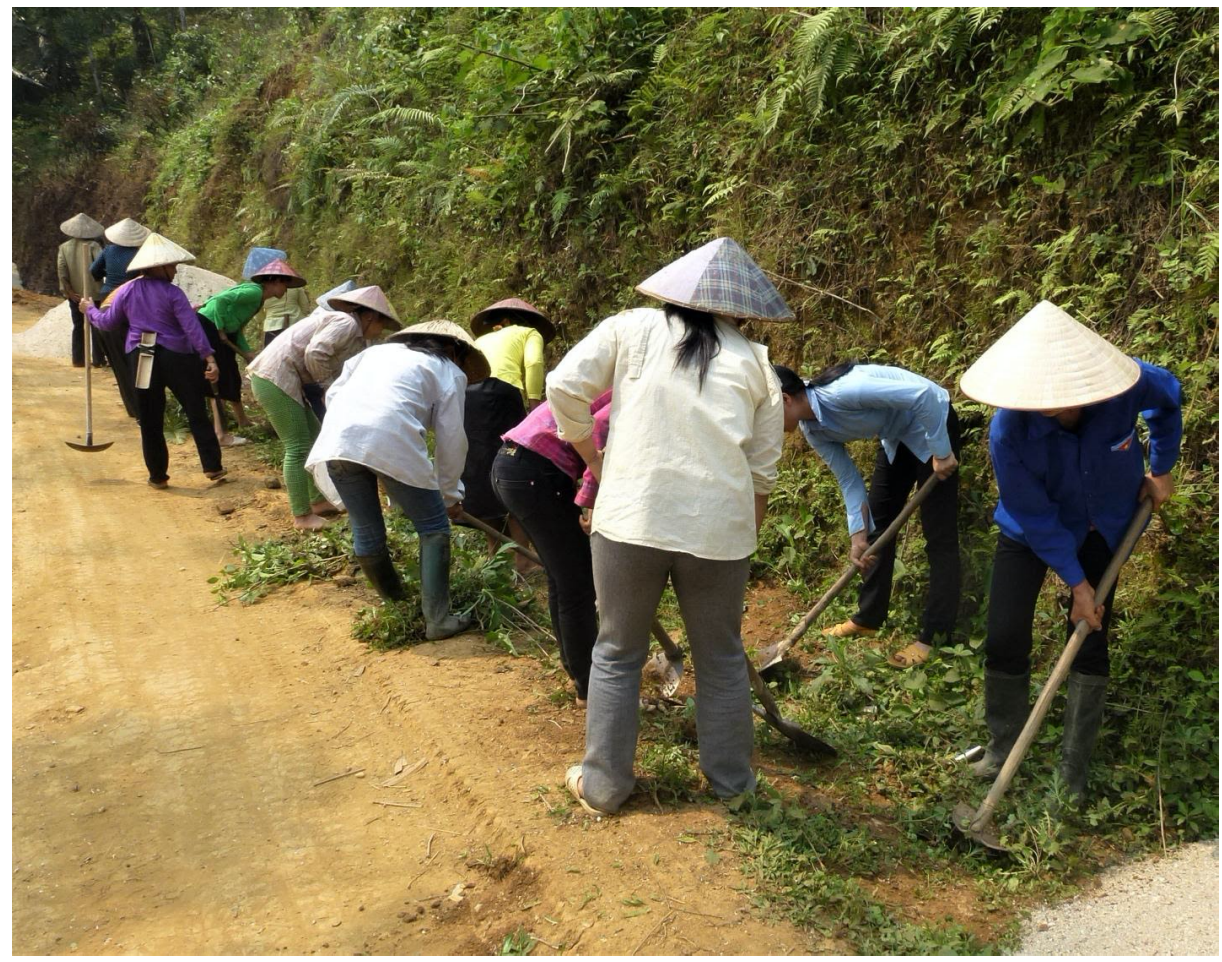

\section{Photo 8. Road Maintenance by Ethnic Minority Women}

Assessing Pilot Outcomes: I assisted the RTP 3 team by using qualitative ethnographic techniques combined with a quantitative survey to assess outcomes for RTP3 and the women-managed road maintenance pilot. We found that RTP3 improved road and market access and provided safer, easier access to urgent health care and school. The percentage of people with year-round road access increased by 10 percent. The percentage of poor households decreased from 27 to 17 percent. Pilot activities improved women's status and voice in households and communities, and enhanced their social capital. A senior official at the Ministry of Transport said, in her view, "RTP3 is the only [Vietnam transport] project that treated women as actors, not just as recipients" (Tran 2011, 2015; World

\footnotetext{
${ }^{5} 628 \mathrm{~km}$ of commune roads; $1,131 \mathrm{~km}$ of inter-village roads; $390 \mathrm{~km}$ of roads to
} fields. 
Bank Hanoi 2014; World Bank Washington DC 2014).

Post-Facto Impact Assessment of RTP3: Three years after the project ended, I participated in the design and analysis of a mixed-methods postfacto impact evaluation by the World Bank East Asia and Pacific Gender Innovation Lab. The aim was to provide more rigorous evidence on whether men and women benefited equally from RTP3 improvements, and to explore the reasons why. Quantitative data (existing household level survey data, and administrative data) were collected and analyzed to evaluate gender-specific impacts of rural road improvements. Qualitative research (interview and focus group discussion), conducted by Vietnamese researchers, explored mechanisms underlying these impacts.

The researchers concluded that, even though roads improved everyone's economic opportunities for agricultural production and trade, only male headed households were able to successfully take advantage of those opportunities to increase their agricultural income. Lack of access to capital, as well as lower levels of household labor and income in female-headed and other vulnerable households, hindered their ability to fully benefit from economic opportunities created by road improvements. Recommendations included coordination of transport investments with other development programs to enable vulnerable households to benefit economically from improved transport infrastructure (Mannava and Perova 2019). ${ }^{6}$

Fostering a "Culture" of Inclusive Road Maintenance: The most significant outcome of the women-managed road maintenance pilots was culture change at the grass roots level. This local change was leveraged by the RTP3 team to influence policy and institutional change at the national level in the Ministry of Transport. At the commune level, the Women's Union awareness-raising campaign reached 765,000 people and engaged 83,545 community members in road maintenance, thus fostering a "culture" of road maintenance. Community members' sense of ownership of and responsibility for local roads resulted in behavior changes, reducing damage, and increasing regular maintenance. At the provincial level, Lao Cai Provincial People's Committee allocated annual funds for road maintenance by the Women's Union and other local groups and contractors for the first time.

At the national level, presentations about the positive outcomes of women-managed rural road maintenance for transport officials at national roundtables and workshops contributed to increased high-level

\footnotetext{
${ }^{6}$ An impact evaluation of gender mainstreaming initiatives in Tanzania's transport sector found similar trends. Few women benefited from employment in road work but most women, particularly the most disadvantages, benefited from the improved road. Women with more resources and independence benefited most from the expanded road services. (Mulongo et. al. 2019).
} 
attention to the need to address road maintenance mechanisms below the provincial level. They recognized the potential of a women-managed approach for sustainable commune and inter-commune rural road maintenance that could be replicated nationwide. The value of campaigns to foster a "culture" of local stewardship of commune roads was also acknowledged. The Deputy Minister of Transport increased resources for staff work on gender equality issues and planned to issue guidance on mainstreaming gender issues into projects. He welcomed World Bank technical support for the Ministry's Committee for the Advancement of Women (CFAW). Given the time required to change attitudes and behavior and achieve institutional and policy changes supporting road maintenance and gender equality in transport, these are very significant outcomes.

Local Asset Management: In 2015, I joined the task team for the Results Based Operation for Local Bridge Construction and Local Road Asset Management Project (LRAMP), and ensured that the lessons from RTP3's women-managed road maintenance pilots were incorporated in the project design and the operational manual. This included replication of a refined version of the women-led approach. The overall objectives of LRAMP are to enhance rural accessibility and connectivity in 14 provinces, lower road users' transport costs, and strengthen local institutional capacity to plan, manage and sustain development of local road and bridge networks. Photo 9 shows an example of a bridge. The bridge component targets poor villages, particularly ethnic minorities, and commune roads with missing or unsafe river crossings in 50 provinces (World Bank 2016).

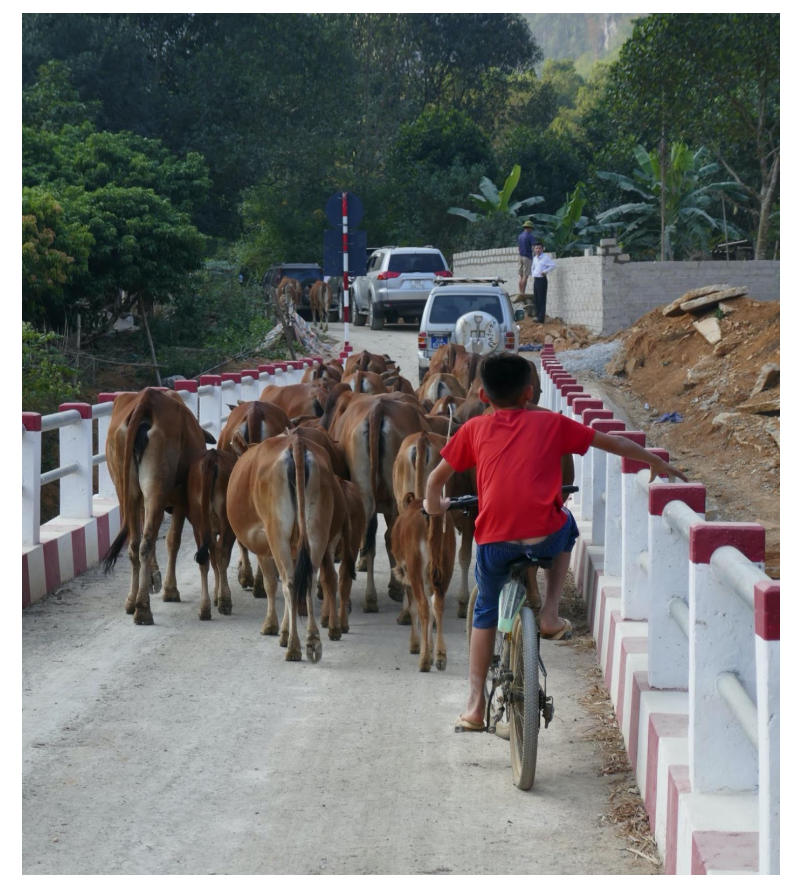

Photo 9. Small Bridges Expand Mobility for Cows, Bicyclist, Pedestrians and Drivers 
Women-led Road Safety Monitoring: We are developing a pilot for womenled rural road safety and road asset monitoring under LRAMP. Like many middle-income countries, Vietnam bears a high burden of road traffic deaths (21, 652 traffic fatalities in 2013). A United Nations Road Safety Performance Review in 2016 found that 30 percent of the accidents occurred on rural roads, nearly 68 percent involved motorbikes, and over 85 percent those killed or injured were men (UNESCAP 2018). The pilot aims to enhance voice and leadership of women in communities, increase road safety, develop a "culture" of road safety awareness and road stewardship, and improve road management. Rural women will use a smart phone application to record and transmit road condition information to the LRAMP Road Assets Management System, and report accidents and safety risks. The Provincial Women's Unions will launch a rural road safety campaign.

This work on gender and community participation in rural transport in Vietnam over nearly a decade illustrates the power of research informing solutions to development problems. It also concretizes the iterative nature of culture change at the grassroots and in state level institutions, leveraged by champions (the World Bank Task Team, the Provincial Women's Union and supporting Provincial Department of Transport staff) who help build a "culture" of inclusive road stewardship at both levels.

\section{Whither Transport Anthropology Theory and Practice?}

Baba and Hall argue that "the future of anthropology is firmly rooted in the theoretical and methodological issues emerging on the frontier of practice" (Baba and Hall 2006, 201). Clearly the plethora of current research on roads and calls for transport anthropology is moving toward such a future. A focus on roads and transportation provides a strategic opportunity for practicing anthropologists to analyze critical issues, identify and implement solutions, assess their influence on policy, and contribute to anthropological theory. The stakes are high; investments in roads and other infrastructure are enormous, as is the potential for negative as well as positive impacts on people affected. ${ }^{7}$

There are many ways in which transport anthropologists can engage in theory and practice to influence policy and programs addressing critical contemporary issues. Participation in practice networks such as GATNET and ANTHROMOB provides a nexus for exchange of practice experience, theory innovations, and mobilizing joint efforts to influence policy (Gatnet n.d., EASA 2019).

\footnotetext{
${ }^{7}$ See Clarke 2012 for a discussion of the challenges faced in transport anthropology practice on interdisciplinary teams in development and transport bureaucracies.
} 
The Transportation Research Board (TRB), part of the U.S. National Academy of Sciences, has a large executive committee which identifies annual critical transport issues and questions framing future policy and research priorities. This committee would benefit from the expertise of a transport anthropologist. ${ }^{8}$ The TRB manages research, convenes experts, and provides policy advice. Some of the critical issues identified by the TRB for 2019 include transformational technologies and services, energy and sustainability, resilience and security, safety and public health, and equity - topics that anthropologists are already examining (Transportation Research Board 2019a).

Multilateral Development Banks ${ }^{9}$ finance infrastructure programs of ministries of transport across the globe and seek innovative approaches to addressing transport challenges. United Nations agencies and non-governmental organizations (NGOs) also address aspects of infrastructure related to health, safety, climate change, gender, and other issues, and seek guidance. Transport agencies in developed and developing countries engage social scientists in planning and evaluation. As I have noted elsewhere, it is extremely important for anthropologists working is specific development sectors, such as transport, to "speak the language" of the engineers and economists working in this field, understand the terminology of transport and the development agency, learn the project design, implementation and evaluation processes, and "translate" anthropological concepts into plain English. Some anthropologists pursue additional degrees or training in international development areas of knowledge and skill. For many, anthropological training facilitates learning the "cultures" of other disciplines (Clarke 2012, 2013).

A focus on ways in which physical networks of roads shape new forms of social life and power relations offers a wide arrange of options to feed the insights of practice into reshaping anthropological theory. Dalakoglou suggest that we need to ask "how we can understand anew established categories of study and analysis (e.g., the house, kinship, migration, technology, and imagination) in reference to the road and vice versa" (Dalakoglou 2017a, 27). Work on infrastructure has already carved out new analytical trajectories for understanding the relations between ecology, technology and culture (Larkin 2013). Examining the spatial dimension pushes the boundaries of our understanding of culture,

\footnotetext{
${ }^{8}$ Members of the TRB executive committee include representatives from all federal and some state transport agencies and some scholars in economics, computer sciences, and one geographer (Transportation Research Board 2019b).

${ }^{9}$ The World Bank, African Development Bank, Asian Development Bank, European Bank for Reconstruction and Development, and InterAmerican Development Bank.
} 
community, gender, and global-local connections to advance anthropological theory (Clarke 2012).

\section{References}

Anand, Nikhil, Akhil Gupta, and Hannah Appel, eds. 2018. The Promise of Infrastructure. Durham: Duke University Press. https://doi.org/10.1215/9781478002031

Appel, Hannah, Nikhil Anand, and Akhil Gupta. 2015a. "The Infrastructure Toolbox." Theorizing the Contemporary, Fieldsights, September 24. https://culanth.org/fieldsights/series/the-infrastructure-toolbox.

Appel, Hannah, Nikhil Anand, and Akhil Gupta. 2015b. "Introduction: The Infrastructure Toolbox." Theorizing the Contemporary, Fieldsights, September 24. https://culanth.org/fieldsights/introduction-theinfrastructure-toolbox.

Argounova-Low, Tatiana. 2012. "Roads and Roadlessness: Driving Trucks in Siberia." Journal of Ethnology and Folklore 6(1):71-88.

. 2017. "Roads in Anthropology: Some Thoughts." Blog post, MSKC (MIND-SETS Knowledge Centre). https://mobilitybehaviour.eu/portfolio/roads-in-anthropology-somethoughts/.

Baba, Marietta L. and Carol E. Hill. 2006. "What's in the Name 'Applied Anthropology'? An Encounter with Global Practice." In The Globalization of Anthropology, ed. Carol E. Hill and Marietta Baba. National Association for the Practice of Anthropology Bulletin 25: 176-207. https://doi.org/10.1525/napa.2006.25.1.176

Bedi, Tarini. 2016. "Taxi Drivers, Infrastructures and Urban Change in Urbanizing Mumbai." City \& Society 28(3): 387-410. https://doi.org/10.1111/ciso.12098

Bishara, Amahl. 2015. "Driving while Palestinian in Israel and the West Bank: The Politics of Disorientation and the Routes of a Subaltern Knowledge." American Ethnologist 42(1):33-54. https://doi.org/10.1111/amet.12114

Bory de Saint-Vincent, J.B.G.M. 1834. Atlas Plate III. Expedition Scientifique de Morée, Section des Sciences Physiques. Paris: F.G. Levrault.

Butt, Anam Parvez and Sharanya Sekaram. 2019. "Smashing Spatial Patriarchy: Shifting Gender Norms Driving Sexual and Gender-Based Violence on Public Transport in Sri Lanka." Oxfam International, July 2019.

https://oxfamilibrary.openrepository.com/bitstream/handle/10546/62 0845/smashing-spatial-patriarchy-gender-based-violence-publictransport-sri-lanka-230719-en.pdf?sequence $=1$ 
Campbell, Jeremy. 2012. "Between the Material and the Figural Road: The Incompleteness of Colonial Geographies in Amazonia." Mobilities 7(4): 481-500. https://doi.org/10.1080/17450101.2012.718429

Cernea, Michael. 1985. Putting People First: Sociological Variables in Rural Development. New York. Oxford University Press (for the World Bank).

2008. "Reforming the Foundations of Involuntary Resettlement: Introduction. In Can Compensation Prevent Impoverishment? Reforming Resettlement through Investments and Benefit Sharing, ed. Michael Cernea and Hari Mohan Mathur. Oxford, Oxford University Press, 1-10.

Clarke, Mari H. 1988. The Transformation of Households on Methana, Greece, 1931-1987. PhD. Dissertation, University of North Carolina at Chapel Hill.

. 1994. "From Shelters to Villas: Changing Household and Settlement Form on Methana 1880-1987." In Constructed Meaning: Form and Process in Greek Architecture, ed. Eleftherios Pavlides and Susan Buck Sutton. Minneapolis: Modern Greek Studies Yearbook 10/11, 1994-95, 511-536.

. 2000. "Changing Household and Economy on Methana." In Contingent Countryside: Settlement, Economy, and Land Use in the Southern Argolid Since 1700, ed. Susan Sutton. Stanford: Stanford University Press, 169-199.

. 2009. "Thematic Note on Rural Roads." In Gender and Agriculture Sourcebook. Washington, DC: World Bank, Food and Agriculture Organization, and International Fund for Agricultural Development, 372382.

2010. Making Transport Work for Women and Men: Tools for Task Teams. Washington, DC: World Bank Social Development. http://siteresources.worldbank.org/EXTSOCIALDEVELOPMENT/Resourc es/244362-1265299949041/67663281270752196897/Making Transport Work for Women and Men.pdf.

. 2011. Building Capacity to Make Transport Work for Women and Men in Vietnam. World Bank East Asia and Pacific Region, Social Development Notes. Washington, DC: World Bank. http://siteresources.worldbank.org/INTEAPREGTOPSOCDEV/Resources /12650GNVietnam.pdf.

2012. "Engendering Transport: Mapping Men and Women on the Move." In Applying Anthropology in the Global Village, ed. Christina Wasson, Mary Odell Butler and Jacqueline Copeland-Carson. Walnut Creek California, Left Coast Press, 57-92.

2013. "International Development." In A Handbook of Practicing Anthropology, ed. Riall Nolan. Chichester, UK, 222-236. https://doi.org/10.1002/9781118486597.ch20

Cook, Cynthia C. 1991. "Social Analysis in Rural Road Projects.” In Putting 
People First: Sociological Variables in Rural Development, ed. Michael M. Cernea. New York: Oxford University Press (for the World Bank), Second Edition, 397-427.

Cosmobilities Network. 2016. Cosmobilities Network: Home. http://www.cosmobilities.net/.

Czegledy, Andre P. 2004. "Getting Around Town: Transportation and the Built Environment in Post-Apartheid South Africa." City \& Society 16(2):63-92. https://doi.org/10.1525/city.2004.16.2.63

Dalakoglou, Dimitris. 2007. "An Anthropology of the Road." Material World Blog, Notes from the Field. https://www.materialworldblog.com/2007/05/an-anthropology-of-theroad/

2010. "An Ethnography of the Albanian-Greek Cross-Border Motorway." American Ethnologist 37(1):132-49. https://doi.org/10.1111/j.1548-1425.2010.01246.x

. 2017a. "Towards an Anthropology of the Roads." Mobility in History 8: 21-27.

2017b. The Road: An Ethnography of (Im)mobility, Space and Cross-

Border Infrastructures in the Balkans. Manchester: Manchester University Press.

Dalakoglou, Dimitris and Penny Harvey. 2012. "Roads and Anthropology: Ethnographic Reflections on Space, Time, and (Im)Mobility." Mobilities 7(4): 459-465.

https://rsa.tandfonline.com/doi/full/10.1080/17450101.2012.718426?s rc=recsys\#.XUzV2uhKjIU https://doi.org/10.1080/17450101.2012.718426

Di Nunzio, Marco. 2018. "Anthropology of Infrastructure." Governing Infrastructure Interfaces - Research Note 01 (June 2018). London School of Economics. https://lsecities.net/wpcontent/uploads/2018/09/Governing-InfrastructureInterfaces Anthropology-of-infrastrcuture MarcoDiNunzio.pdf

EASA (European Association of Social Anthropologists). 2019. ANTHROMOB: Anthropology and Mobility Network. Last updated 10 October 2019. https://www.easaonline.org/networks/anthromob/

Economou, Leonidas. 2014. "Political and Cultural Implications of the Suburban Transformation of Athens." In Crisis-Scapes: Athens and Beyond. Athens: Crisis-Scape.net.

https://research.vu.nl/ws/portalfiles/portal/1339137/CrisisScapesConf erenceBookWeb\%281\%29.pdf

Fairhead, James. 1992. "Paths of Authority: Roads, the State, and the Market in Eastern Zaire." Journal of European Development Research 4(3): 17-35. https://doi.org/10.1080/09578819208426569 
Ference, Meghan. 2016. "Together We Can: Redefining Work in Nairobi's Urban Transportation Sector." Anthropology of Work Review 37(2): 101112. https://doi.org/10.1111/awr.12098

Fernando, Priyanthi and Gina Porter, eds. 2002. Balancing the Load: Women, Gender, and Transport. London: Zed Books.

Firat, Bilge. 2016. "'The Most Eastern of the West, the Most Western of the East': Energy-Transport Infrastructures and Regional Politics of the Periphery in Turkey." Economic Anthropology 3: 21-93. https://doi.org/10.1002/sea2.12046

Gaither, Cassandra, David Himmelfarb, Sarah Hitchner, John Chelhas, and J. Marshall Shepherd. 2016. "Where the Sidewalk Ends: Sustainable Mobility in Atlanta's Cascade Community." City \& Society 28(2): 174-97. https://doi.org/10.1111/ciso.12077

Gardner, Andrew. 2002. "The Long Haul from Deregulation: Truck Drivers and Deregulation in the Louisiana Oil Patch." Human Organization 61(2): 390-398. https://doi.org/10.17730/humo.61.4.6hm956ykpd5xd9e0

Gatnet. n.d. Gatnet - Gender and Transport Community of Practice. Latest version of original website:

https://dgroups.org/worldbank/gatnet/; Expanded Resources Gender Equity and Transport Forum on Facebook: https://www.facebook.com/groups/gatnet/

Google Earth. 2019. "Methana." August 13, 2019.

https://earth.google.com/web/@37.5823067,23.36098192,54.61397617 a,7118.45932716d,35y,0h,48.57085701t,0r

Gluckman, Max. 1940. "Analysis of a Social Situation in Modern Zululand." Bantu Studies 14(4): 1-30.

https://doi.org/10.1080/02561751.1940.9676107

Great Britain, Naval Intelligence Division. 1945. Greece Geographical Handbook, Series BR 516. London: His Majesty's Stationer.

Guitierrez, Maria T. 2003. Case Study: Peru Transport Rehabilitation Project. Prepared for Integrating Gender into World Bank Financed Transport Programs. Washington, DC: World Bank.

Gutierrez, Maria T. and Maria Kuiper. 2010. Women in Infrastructure Work: Boosting Gender Equality and Rural Development. Gender and Rural Employment Policy Brief no. 5. Washington, DC: Food and Agriculture Organization, International Fund for Agricultural Development, International Labor Organization. http://www.fao.org/3/i2008e/i2008e05.pdf

Haddington, Pentti and Mirka Rauniomaa. 2016. "Interaction Between Road Users: Offering Space in Traffic." Space and Culture 17(2): 176-190. https://doi.org/10.1177/1206331213508498 
Handman, Courtney. 2017. "Walking Like a Christian: Roads, Translation, and Gendered Bodies as Religious Infrastructure in Papua New Guinea." American Ethnologist 44(2):315-27. https://doi.org/10.1111/amet.12481 Harnish, Allison, Lisa Cliggett, and Thayer Scudder. 2018. “Rivers and Roads: A Political Ecology of

Displacement, Development, and Chronic Liminality in Zambia's Gwembe Valley." Economic Anthropology 6:250-263.

Harvey, Penny and Hannah Knox. 2016. Roads: An Anthropology of Infrastructure and Expertise. Ithaca: Cornell University Press. https://doi.org/10.7591/9780801456466

Hayano, David M. 1990. Road Through the Rainforest: Living Anthropology in Highland Papua New Guinea. Prospect Heights, Illinois: Waveland Press.

Heslop, Luke. 2016. "Book Review: An Anthropology of Infrastructure and Expertise by Penny Harvey and Hannah Knox." London School of Economics Review of Books. January 18, 2016.

https://blogs.lse.ac.uk/lsereviewofbooks/2016/01/18/book-reviewroads-an-anthropology-of-infrastructure-and-expertise-by-pennyharvey-and-hannah-knox/

Infra-Demos. 2017. About Infra-Demos. http://www.infrademos.net/about.html

Karak, Madhuri. 2016. “Choosing Paths Not Roads." Engagement: Blog of the Anthropology and Environment Society.

https://aesengagement.wordpress.com/2016/05/24/choosing-pathsnot-roads/

Kernaghan, Richard. 2016. "Furrows and Walls, or the Legal Topography of a Frontier Road in Peru." Mobilities 7(4):501-520.

https://doi.org/10.1080/17450101.2012.718932

Khan, Naveeda. 2006. "Flaws in the Flow: Roads and their Modernity in Pakistan." Social Text 89 (4): 87-113. https://doi.org/10.1215/01642472$\underline{\text { 2006-012 }}$

Kudat, Ayse. 1996. A Case Study for Social Support of Transport in Ashgabat. Washington, DC: World Bank.

Kudat, Ayse, Stan Peabody, Ovezdurdy Muhammertberdiev, and Klaus Moeltner. 1997. "Strengthening Ashgabat's Urban Transport Sector." In Social Assessments for Better Development: Case Studies in Russia and Central Asia, ed. Michael Cernea and Ayse Kudat. Washington, DC: World Bank, 165-186.

Larkin, Brian. 2013. "The Politics and Poetics of Infrastructure." Annual Review of Anthropology 47:327-43. https://doi.org/10.1146/annurevanthro-092412-155522

Lévi-Strauss. 1971. Interview: Claude Lévi-Strauss." Diacritics 1(1):44-50. 
https://doi.org/10.2307/464559

Lombard, Louisa. 2013. "Navigational Tools for Central African

Roadblocks." Political and Legal Anthropology Review 36(1): 157-173. https://doi.org/10.1111/plar.12008

Mannava, Aneesh and Elizaveta Perova. 2019. Who Benefits from Roads and Why? Mixed Methods Analysis of the Gender Disaggregated Impact of a Rural Roads Project in Vietnam. Washington, DC: World Bank East Asia and Pacific Gender Innovation Lab. https://doi.org/10.1596/1813-9450$\underline{9216}$

Mains, Daniel and Eshetayehu Kinfu. 2017. "Governing Three-Wheeled Motorcycle Taxis in Urban Ethiopia: States, Markets, and Moral Discourses of Infrastructure." American Ethnologist 44, no.2 (2017):263274. https://doi.org/10.1111/amet.12477

Masquelier, Adeline. 2002. "Road Mythologies, Space, Mobility, and the Historical Imagination in Post Colonial Niger." American Ethnologist 29(4): 829-56. https://doi.org/10.1525/ae.2002.29.4.829

Menezes, Deborah. 2017. “'First They Build Our Roads and Then They Take Our Lands': Road '(Re-) Construction' in Post-War Sri Lanka." Paper presented at International Workshop on Roadology, SUSTech University, Shenzhen, China. https://researchportal.hw.ac.uk/en/publications/firstthey-build-our-roads-and-then-they-take-our-lands-road-reco Moran, Emilio. 1981. Developing the Amazon: The Social and Ecological Impact of Settlement Along the Trans-Amazon Highway. Bloomington: Indiana University Press.

Mulongo, Godfrey, Gina Porter, and Amleset Twodros. 2019. "Gendered Politics in Rural Roads: Gender Mainstreaming in Tanzania's Transport Sector." Proceedings of the Institution of Civil Engineers - Transport. https://doi.org/10.1680/itran.18.00153

Netting, Robert McC. 1993. Smallholders, Householders: Farm Families and the Ecology of Intensive, Sustainable Agriculture. Stanford: Stanford University Press.

Netting, Robert McC., Richard R. Wilk, and Eric J. Arnould, eds. 1984. Households: Comparative and Historical Studies of the Domestic Group. Berkeley: University of California Press.

Pedersen, Morton Axel, and Mikkel Bunkenborg. 2012. "Roads that Separate: Sino-Mongolian Relations in the Inner Asian Desert." Mobilities 7(4): 555-569. https://doi.org/10.1080/17450101.2012.718938

Pina-Cabral, Joao. 1987. "Paved Roads and Enchanted Mooresses: The Perceptions of the Past Among the Peasant Population of the Alto-Minho." Man (new series) 22: 715-735. https://doi.org/10.2307/2803360

Porter, Gina. 2002. "Living in a Walking World: Road Mobility and Social 
Equity Issues in Subsaharan Africa." World Development 30(2): 285-300. https://doi.org/10.1016/S0305-750X(01)00106-1

Riverson, John, Mika Kunieda, Peter Roberts, Negede Lewi, and Wendy Walker. 2006. An Overview of Women's Transport Issues in Developing Countries and Challenges in Addressing Gender Dimensions of Transport in Developing Countries: Lessons from World Bank's Projects. Transport Research Board Annual Meeting CD-ROM, 2006.

https://doi.org/10.1177/0361198106195600119

Rodriguez, Cheryl and Beverly Ward. 2018. "Making Black Communities Matter: Race, Space, and Resistance in the Urban South." Human Organization 77(4):312-322. https://doi.org/10.17730/0018$\underline{7259.77 .4 .312}$

Roseman, Sharon. 1996. "How We Built the Road: The Politics of Memory in Rural Galicia." American Ethnologist 23(4): 836-60.

https://doi.org/10.1525/ae.1996.23.4.02a00090

Rosin, Thomas. 2003. "Vishnu and the Art of Motor Cycle Driving: Toward an Anthropology of Traffic." Kroeber Anthropological Society Papers 80/90: 56-70.

Schorr, Thomas. 2017. "Methana Tourist Map." https://www.methana.com/fileadmin/pdf uploads/methana pdf/metha na tourist map 2017.pdf

Scudder, Thayer. 2007. "A History of Development and Downturn in Sambia's Gwembe Valley." In Tonga Speaking Peoples of Zambia and Zimbabwe, ed. Chet Lancaster and Kenneth Vickery. New York: University Press of America, 307-343.

Sheller, Mimi. 2015. "Racialized Mobility Transitions in Philadelphia: Connecting Urban Sustainability and Transport Justice." City \& Society 27(1): 70-91. https://doi.org/10.1111/ciso.12049

Sherouse, Perry Maxfield Waldman. 2018. "Where the Sidewalk Ends: Automobility and Shame in Tbilisi, Georgia". Cultural Anthropology 33(3): 444-472. https://doi.org/10.14506/ca33.3.07

Smith, Carol, ed. 1976. Regional Analysis Volume I: Economic Systems. New York: Academic Press.

SOAS. 2019. "Roads and the Politics of Thought: Ethnographic Approaches to Infrastructure Development in South Asia."

https://www.soas.ac.uk/anthropology/research/roads/

Sopranzetti, Claudio. 2014. "Owners of the Map: Mobility and Mobilization among Motorcycle Taxi Drivers in Bangkok. City \& Society 26(1): 120-43. https://doi.org/10.1111/ciso.12030

Star, Susan Leigh. 1999. "Ethnography of Infrastructure." American Behavioral Scientist 42(3): 377-91. 
https://doi.org/10.1177/00027649921955326

Stewart, Pamela and Andrew Strathern. 1999. "Death on the Move: Landscape and Violence on the Highlands Highway, Papua New Guinea." Anthropology and Humanism 24(1): 20-31. https://doi.org/10.1525/ahu.1999.24.1.20

Stoetzer, Bettina. 2018. "Infrastructure - Peripheral Visions and Bodies that Matter: A Commentary." Engagement: Blog of the Anthropology and Environment Society, July 2018. https://aesengagement.wordpress.com/2016/08/23/infrastructureperipheral-visions-and-bodies-that-matter-a-commentary/

Tran, Phuong Thi Minh. 2011. Pathways to Development: Empowering Local Women to Build a More Equitable Future in Vietnam. International Finance Corporation Smart Lessons, October 2011. Washington, DC: International Finance Corporation, World Bank Group. http://smartlessons.ifc.org/smartlessons/lesson.html?id=1495

. 2015. "Empowering Local Women to Build a More Equitable Future in Vietnam." World Bank Blog (July 8, 2015).

https://blogs.worldbank.org/transport/empowering-local-women-buildmore-equitable-future-vietnam

Trankell, Inge-Britt. 1993. On the Road to Laos: An Anthropological Study of Road Construction and Rural Communities. Uppsala, Sweden: Upsala Reports in Cultural Anthropology 12.

Transportation Research Board. 2019a. Critical Issues in Transportation 2019. Washington, DC: The National Academies Press. https://www.nap.edu/catalog/25314/critical-issues-in-transportation$\underline{2019}$

2019b. Home Page, Transportation Research Board. http://www.trb.org/Main/Home.aspx

Truitt, Allison. 2008. "On the Back of a Motorbike: Middle-Class Mobility in Ho Chi Minh City, Vietnam." American Ethnologist 35(1):3-19. https://doi.org/10.1111/i.1548-1425.2008.00002.x

United Nations Economic and Social Commission for Asia and the Pacific (UNESCAP). 2018. Road Safety Performance Review: Vietnam. New York: United Nations.

https://www.unece.org/fileadmin/DAM/trans/roadsafe/unda/RSPR Vie t Nam FULL e.pdf

Uribe, Simon. 2019. "Illegible Infrastructures: Road Building and the Making of State-Spaces in the Colombian Amazon." Environment and Planning D: Society and Space 37(5):886-904. https://journals.sagepub.com/doi/10.1177/0263775818788358 https://doi.org/10.1177/0263775818788358

Uzzell, Denis. 1987. “A Home Grown Mass Transit System in Lima, Peru: A 
Case of Generative Planning." City \& Society 1(1): 6-34.

https://doi.org/10.1525/city.1987.1.1.6

Vajjha, Salini and Wendy Walker. 2009. Roads to Participatory Planning:

Integrating Cognitive Mapping and GIS for Transport Prioritization in Rural Lesotho. RFF Discussion Paper RFF DP 09-26. Washington, DC: Resources for the Future. https://doi.org/10.2139/ssrn.1473928

Wallace, Anthony. 1971. "Driving to Work." In Culture and Cognition: Rules, Maps and Plans, ed. James Spradley. San Francisco: Chandler, 31026.

Walker, Wendy, Shalini Vajjhala, and Thasi Phomane. 2005. Ground Truthing: Mobility Mapping and Access in Rural Lesotho. Washington, DC: World Bank and Lesotho Ministry of Public Works.

Williamson, Thomas. 2002. "The Fluid State: Malaysia's National Expressway." Space and Culture 6(2): 110-31. https://doi.org/10.1177/1206331203251255

World Bank. 2006. Project Appraisal Document for a Third Rural Transport Project, Vietnam. Washington, DC: World Bank, Transport Sector Unit, East Asia and Pacific Region.

. 2014. Implementation Completion Report: Vietnam Third Rural Transport Project. Washington, DC: World Bank, Transport Sector, East Asia and Pacific Region.

2014. Empowering Women to Build a More Equitable Future in Vietnam: Assessment of the Provincial Women's Union Woman-Managed Routine Rural Road Maintenance Program. Washington, DC: World Bank, Transport Sector, East Asia and Pacific Region.

2016. Program Appraisal Document for a Results Based Operation for Local Bridge Construction and Road Asset Management, Vietnam. Washington, DC: World Bank, Transport Sector, East Asia and Pacific Region.

Yarrington, Landon. 2015. "The Paved and the Unpaved: Toward a Political Economy of Infrastructure, Mobility, and Urbanization in Haiti." Economic Anthropology 2: 185-201. https://doi.org/10.1002/sea2.12024 Yazici, Berna. 2013. "Towards an Anthropology of Traffic: A Ride Through Class Hierarchies in Istanbul's Roadways." Ethnos 78(4):515-542. https://doi.org/10.1080/00141844.2012.714395 
Zhang, Jun. 2016. "Taxis, Traffic, and Thoroughfares: The Politics of Transportation Infrastructure in China's Rapid Urbanization in the Reform Era." City \& Society 28(3):411-36.

https://doi.org/10.1111/ciso.12099

Mari H. Clarke is a World Bank Senior Gender Consultant and has worked with the World Bank on gender and transport since FY2005. She is a member of the World Bank task team for the Vietnam Local Road Asset Management Program and the inclusion team of Global Water Practice. In 2015, she received the Praxis Award for excellence in the application of anthropological theory and practice for her work in Vietnam. She managed a support project for the USAID Office of Private and Voluntary Cooperation and led a project supporting the USEgyptian Education Partnership. She also worked with the US Agency for International Development, Office of Women and Development, for eight years. She served as President of the Washington Association of Professional Anthropologists and Secretary of the National Association for the Practice of Anthropology. She has a PhD in Economic Anthropology and a M.Ed. in Instructional Design from the University of North Carolina in Chapel Hill. 